\title{
Standardization of Patient Handovers From the Operating Room to the Surgical Intensive Care Unit: A Quality Improvement Project
}

Jacob S. Key

jkey1@mix.wvu.edu

Follow this and additional works at: https://researchrepository.wvu.edu/etd

\section{Recommended Citation}

Key, Jacob S., "Standardization of Patient Handovers From the Operating Room to the Surgical Intensive Care Unit: A Quality Improvement Project" (2022). Graduate Theses, Dissertations, and Problem Reports. 10178.

https://researchrepository.wvu.edu/etd/10178

This Dissertation is protected by copyright and/or related rights. It has been brought to you by the The Research Repository @ WVU with permission from the rights-holder(s). You are free to use this Dissertation in any way that is permitted by the copyright and related rights legislation that applies to your use. For other uses you must obtain permission from the rights-holder(s) directly, unless additional rights are indicated by a Creative Commons license in the record and/ or on the work itself. This Dissertation has been accepted for inclusion in WVU Graduate Theses, Dissertations, and Problem Reports collection by an authorized administrator of The Research Repository @ WVU.

For more information, please contact researchrepository@mail.wvu.edu. 
Standardization of Patient Handovers From the Operating Room to the Surgical Intensive Care Unit: A Quality Improvement Project

Jacob S. Key, BSN, SRNA

Doctor of Nursing Dissertation submitted

to the School of Nursing

at West Virginia University

in partial fulfillment of the requirements for the degree of

Doctor of Nursing Practice in

Nurse Anesthetist Program

\author{
Mike Frame, DMPNA, MS, APRN, CRNA, Chair \\ Miranda Nuzum, BSN, RN, CCRN, CFRN, ME-BC \\ Kesheng Wang, $\mathrm{PhD}$, MA, BS \\ Department of Nursing
}

Morgantown, West Virginia

2021

Keywords: patient handovers, intensive care unit, operating room, quality improvement Copyright 2021 Jacob Key 


\begin{abstract}
Standardization of Patient Handovers From the Operating Room to the Surgical Intensive Care

Unit: A Quality Improvement Project
\end{abstract}

Jacob S. Key

Background: Patient handovers from operating rooms (ORs) to intensive care units (ICUs) frequently endure communication breakdowns and poor staff satisfaction when standardized handover procedures (SHPs) are not in place. Purpose: The project's purpose was to assess the impact of a SHP checklist on OR to surgical ICU (SICU) handover staff satisfaction and perceptions regarding the patient handover process at a Level 1-designated trauma academic hospital. Interventions: Pre- and post-project staff satisfaction surveys were conducted after four months of SHP checklist introduction and utilization. Methods: SHP checklist and survey formation were based on similar quality improvement (QI) project designs revealed during a comprehensive literature review. Surgeons, anesthesia providers, and ICU nurses were asked to complete surveys. Forty-five handovers using the developed SHP were utilized to fulfill sample size requirements. Statistical analyses were performed to compare pre- and post-implementation survey scores. Results: The project entailed 45 handovers utilizing the SHP checklist over two months in addition to 52 and 47 surveys submitted by handover staff one month before and after project execution, respectively. Each of the three services' pre-survey and post-survey resultant mean comparisons revealed two questions with statistically significant findings. Conclusion: After implementation of a SHP checklist, SICU RNs, anesthesia providers, and surgery team members conveyed increased satisfaction with the overall handover process, patient information communicated during handovers, reduced distractions, and increased staff presence although checklist usage was inconsistent. 


\section{Table of Contents}

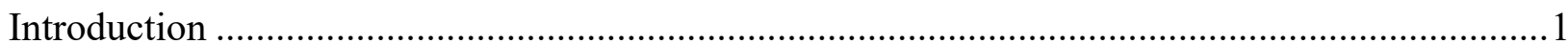

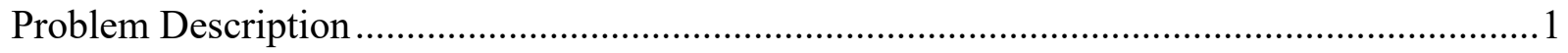

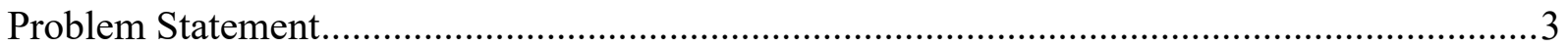

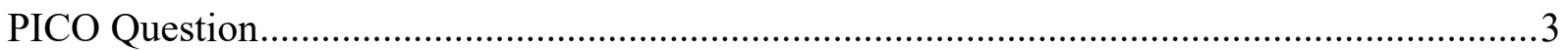

Literature Review and Synthesis ...............................................................................

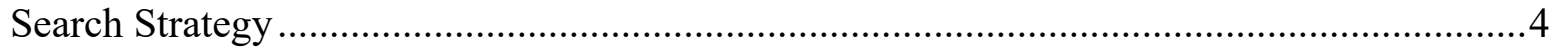

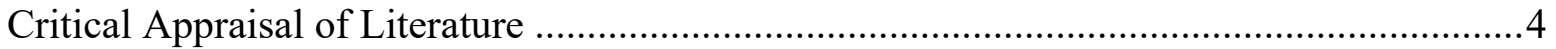

Literature Review Synthesis ........................................................................................ 10

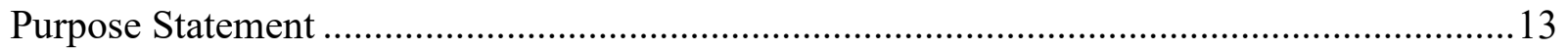

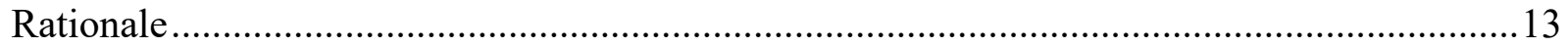

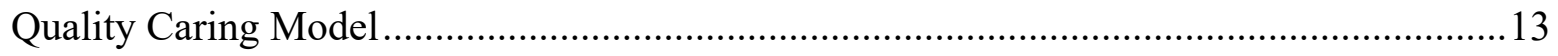

Focus, Analyze, Develop, Execute (FADE) Model ..................................................... 14

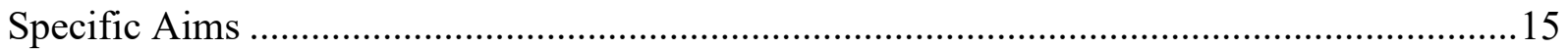

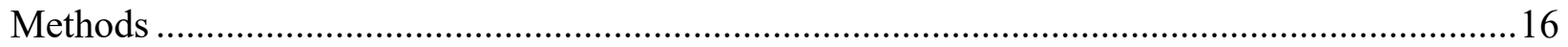

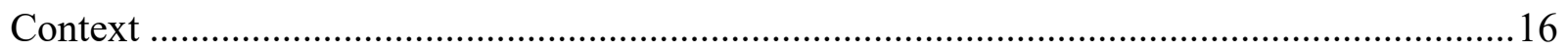

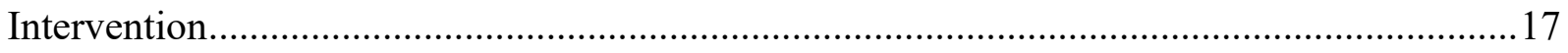

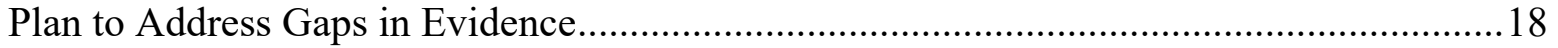

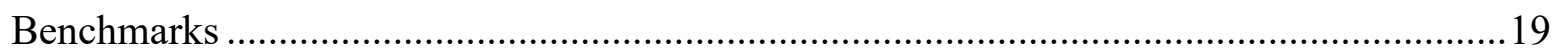

Congruence With the Organization's Strategic Plan...................................................... 19

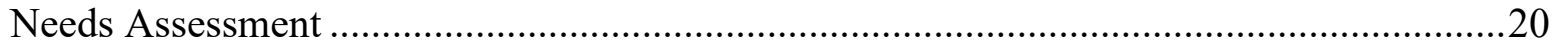

Strengths, Weaknesses, Opportunities, Threats (SWOT) Analysis .................................20

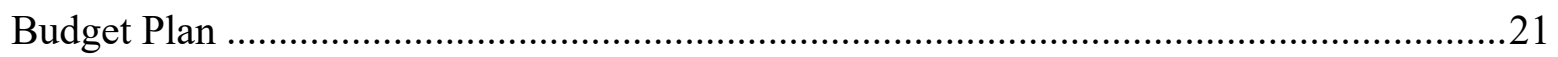

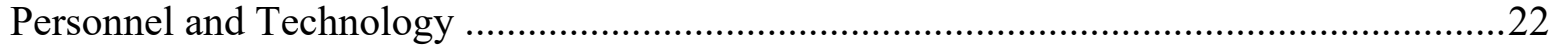

Sustainability of the Proposed Project............................................................................22

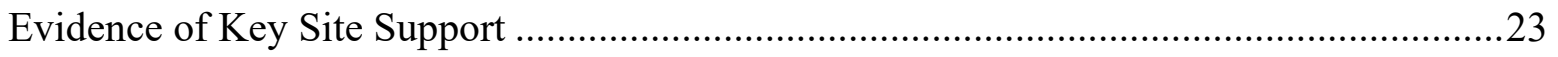

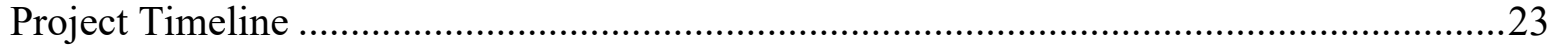

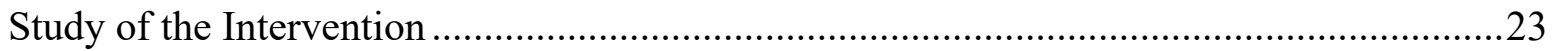




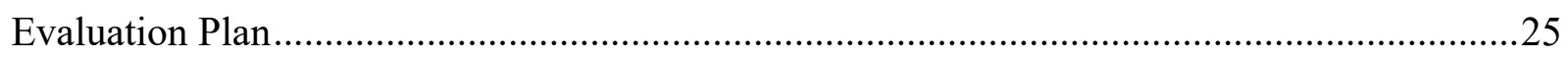

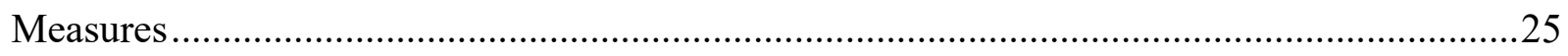

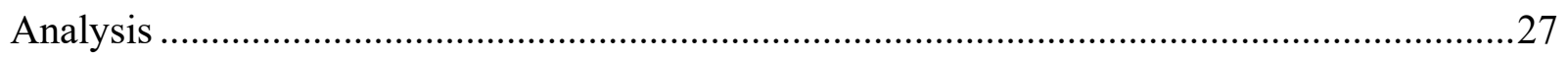

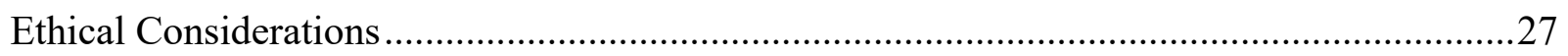

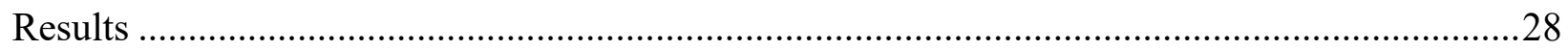

Intervention Steps and Evolution Over Time .....................................................................28

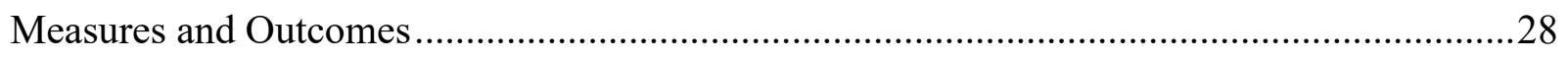

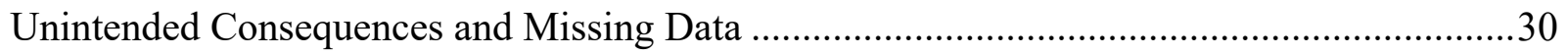

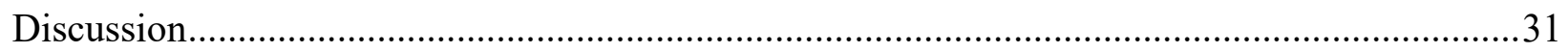

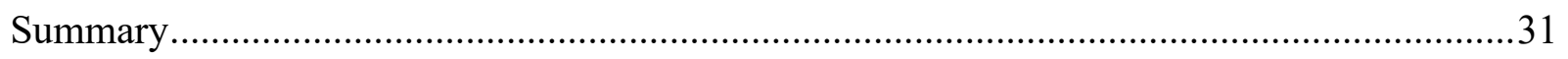

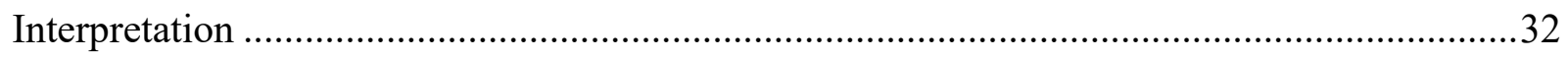

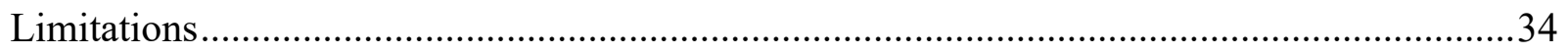

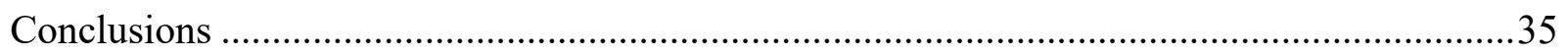

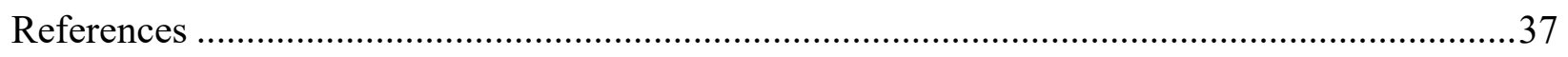

Appendix A: Literature Review and Synthesis Table .............................................................

Appendix B: Pre- and Post-implementation Questionnaire ………………….............................67

Appendix C: Standardized Handover Process Checklist..............................................................69

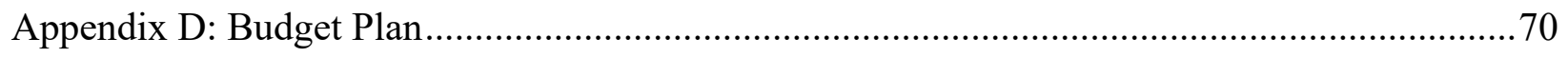

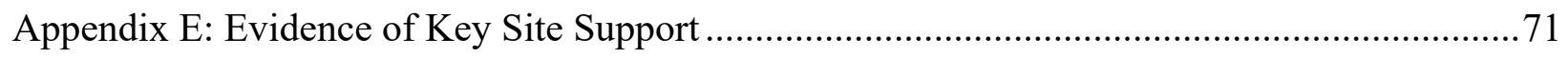

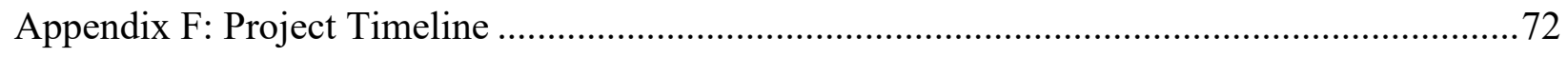

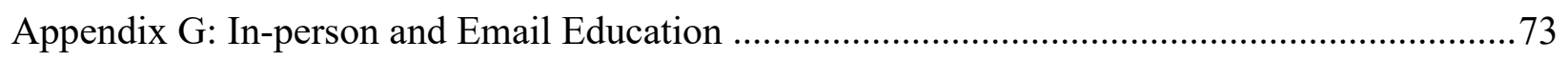

Appendix H: SICU RN Survey Results Comparison ................................................................

Appendix I: Anesthesia Provider Survey Results Comparison .....................................................

Appendix J: Surgery Service Member Survey Results Comparison..............................................79 
Appendix K: Survey Respondent Free-Text Answers ....................................................... 81 


\section{Standardization of Patient Handovers From the Operating Room to the Surgical Intensive Care Unit: A Quality Improvement Project}

Patient handovers between operating room (OR) and intensive care unit (ICU) providers regularly result in communication errors and omissions of pertinent information (Segall et al., 2012). According to Zaman and Ali (2018), a patient handover is defined as "the transfer of care of patient(s) to other health care provider(s). It encompasses handing over of professional responsibilities, obligations and accountability on a short-term or long-term basis" (p. 233). Common sources of patient handover communication breakdowns from the OR to the ICU include frequent interruptions of handover reports, distractions due to ICU registered nurses (RNs) attempting to receive report while simultaneously performing numerous tasks, and vexations caused by the lack of standardized post-operative handover protocols or checklists (Krimminger et al., 2018; Nagpal et al., 2010; Wheeler et al., 2018).

Advanced practice registered nurses (APRNs), such as certified registered nurse anesthetists (CRNAs) and nurse practitioners (NPs), often collaborate with perioperative interprofessional teams. Improving handover communication of a patient's history, procedural interventions, current status, and anticipated needs may lead to improved patient care and eventual patient outcomes. A relative abundance of literature exists demonstrating that the employment of standardized interventions targeting the aforementioned sources of communication failures enhances communication flow and improves satisfaction among interprofessional members involved in the post-operative handover process.

\section{Problem Description}

Patient handovers from the OR to the ICU present unique circumstances and challenges compared to other hospital transfers. Interprofessional team members often describe 
miscommunication concerns and dissatisfaction with patient handovers when consistent protocols are not in place. Post-operative ICU patients are commonly transferred to the unit accompanied by a great deal of items and equipment, such as monitoring devices, life-supporting medications, and implanted devices; and a multitude of anesthesia and surgery team members (Talley et al., 2019). Admitting ICU RNs frequently report dissatisfaction with their handover reports due to the high variability in report structure, the absence of a surgery team member, the distractions associated with multitasking while receiving report, and the occurrence of repeated interruptions (Krimminger et al., 2018; Marshall et al., 2019). Losing focus due to simultaneous conversations, having to repeat information to multiple ICU members, and locating the admitting $\mathrm{RN}$ are areas of discontent generally expressed by OR staff transferring the post-operative patient (Lane-Fall et al., 2020; Marshall et al., 2019; Van Der Walt et al., 2016).

Several reputable health care organizations dedicated to patient safety and wellbeing have published patient handover enhancement initiatives and recommendations within the last six years. The Joint Commission (2017) claimed in 2016 that over a five-year span, ineffective communication was linked to $\$ 1.7$ billion in malpractice lawsuits and 1,744 deaths in U.S. hospitals. Two handover quality improvement recommendations made by the Joint Commission include standardizing the handover technique while incorporating both verbal and written methods and minimizing interruptions during the handover report. In 2014, the World Health Organization (WHO) identified five global health care circumstances, designated the "High 5s," contributing the most to patient safety disturbances. Communication during patient handovers was branded as one of the "High 5s," so the WHO recommends employing standardized procedures in the patient handover process to mitigate communication errors and reduce patient harm (Leotsakos et al., 2014). 


\section{Problem Statement}

Distractions, interruptions, team member absence, and a lack of standardized handover protocols can diminish communication, squander time resources of interprofessional teams, and increase errors and potential for patient harm during and soon after patient handovers.

Development and implementation of a standardized protocol checklist should be completed to diminish communication barriers and improve staff satisfaction associated with patient handover procedures.

\section{PICO Question}

A tool commonly utilized by health profession students is the population, intervention, comparison, outcome (PICO) question. The PICO question is exercised to help guide literature reviews and develop a project for clinical implementation (Kloda et al., 2020). After considering a modern health care concern and developing a problem statement, the following PICO question was formulated. In an adult surgical ICU (SICU), does the utilization of a standardized postoperative handover checklist compared to current handover practices affect surgery, anesthesia, and nurse handover communication and satisfaction during OR to ICU patient handovers?

\section{Literature Review and Synthesis}

The purpose of the comprehensive literature review was to locate and evaluate available research and evidence pertaining to the effects of standardized handover protocols (SHPs) on the transfer of patients from the OR to ICUs. Specifically, the review concentrated on SHPs emphasizing reductions in bedside report distractions, interruptions, and parallel conversations to allow OR staff and receiving ICU RNs to communicate imperative perioperative patient information and ask questions. Findings from the literature review, particularly SHP sequences 
and outcomes based on satisfaction survey scores after SHP implementation, were used to guide project development, execution, and outcome measurement strategies. The review focused on adult patients transferred directly from the OR to the ICU and excluded pediatric patients and adults transferred to any hospital unit other than the ICU (including the post-anesthesia care unit (PACU)).

\section{Search Strategy}

Literature databases searched included PubMed, CINAHL/EBSCOhost, Elsevier/Clinical Key, Cochrane Library, and West Virginia University’s (WVU) comprehensive online database library. Search terms included "OR," "ICU," "transfer," "operating room," "handover," "handoff," and "intensive care unit." Some searches were revised before analyzing resultant items due to hundreds or sometimes thousands of search results. Individual results were initially deemed appropriate if search terms or phrases were included in titles and/or abstracts, and additional analysis produced 22 potentially relevant journal articles. Further evaluation resulted in 15 of those articles being excluded due to the lack of statistical data or because the outcomes measured differed from the project's interest.

\section{Critical Appraisal of Literature}

A total of seven observational quality improvement (QI) studies were deemed relevant and examined the impact of newly implemented SHPs for OR to ICU patient transfers. All studies were given a United States Preventive Services Task Force (USPSTF, 2020) Grade B recommendation based on a moderate level of certainty that each study's results showed a net benefit. Seven articles were ultimately credited as significant in relation to the PICO question, and each article was subsequently appraised using Scottish Intercollegiate Guidelines Network (SIGN) or Larrabee appraisal tools. Each study's purpose, design and methods, setting, and 
findings were summarized and entered into Table 1 to aid with study comparisons (see Appendix A).

Krimminger et al. (2018) conducted a quality improvement QI observational study in a 21-bed cardiothoracic intensive care unit (CTICU) at a large university-affiliated medical center. One purpose of the study was to assess healthcare workers' satisfaction with a newly implemented SHP used during OR to ICU handovers. Anesthesia, surgery, perioperative, and ICU team members helped develop the SHP checklist, and the sequence of the checklist was as follows: patient and provider bedside verbal introductions, equipment handover, and finally verbal handover beginning with anesthesia and ending with surgery. No interruptions and the presence of anesthesia, surgery, and RNs were encouraged by the SHP, and the report did not conclude until all clinicians' questions were answered. One month was required to educate participants on the use of the new SHP, and laminated checklists were created and placed in all ICU rooms and offered to providers in pocket-sized versions.

A total of 38 handovers were observed before and after SHP implementation in the Krimminger et al. (2018) study. Likert-scale surveys were used prior to and following SHP implementation to assess anesthesia, surgery, and ICU RN satisfaction score improvements with the new SHP. Statistically significant improvements (defined as $\mathrm{p}<0.05$ ) included improved satisfaction with surgery's report $(\mathrm{p}=0.008)$, improved satisfaction with anesthesia's report $(p=0.01)$, improved ability to hear all of the report $(p=0.003)$, decreased interruptions impairing the handover process $(\mathrm{p}=0.017)$, improved clarification of when the handover began and ended $(\mathrm{p}<0.001)$, and improvements in decreased feelings of time pressure for those handing off the patient $(\mathrm{p}=0.008)$ and those receiving the patient $(\mathrm{p}=0.002)$. 
Talley et al. (2019) conducted a QI observational study at a University of Maryland tertiary care center adult SICU with the purpose of standardizing the verbal and written postoperative handover procedure between the hospital's OR and SICU to enhance providers' communication and satisfaction with the process. The SHP was designed and revised a few times after pilot studies by surgeons, anesthesia representatives, ICU RNs, ICU APRNS, and other SICU staff (managers and unit leaders). The SHP implemented progresses in the following order: patient arrives, and equipment and monitors are transferred, SICU physician states report is to begin, surgery reports, anesthesia reports, questions are answered among all staff, and report terminates. SHP education was enforced over one month via emails, in-person huddles, staff meetings, and grand rounds, and signs with the SHP diagram were placed at in each patient room in the SICU.

The Talley et al. (2019) study used Likert-surveys assessing satisfaction were completed by ICU RNs receiving post-operative patients before and after SHP implementation. Statistically significant improvements (defined as scores with $\mathrm{p}<0.05$ ) consisted of increased number of actual reports received from surgeons $(\mathrm{p}<0.001)$, satisfaction with surgeon handoff reports $(\mathrm{p}<0.001)$, satisfaction with the ability to identify surgeons during handoff $(\mathrm{p}<0.001)$, satisfaction with feeling included during handover $(\mathrm{p}<0.001)$, decreased frequency of feeling too busy with routine activities during handoff $(\mathrm{p}=0.004)$ and too busy with urgent activities during handoff ( $\mathrm{p}<=0.002$ ). Of note, anesthesia report satisfaction scores improved, but not significantly because satisfaction scores were much higher before SHP implementation compared to surgeon reports prior to SHP implementation.

Petrovic et al. (2012) performed an observational QI study in a large tertiary center's cardiac surgical ICU (CSICU) that evaluated the effect of a new SHP on provider satisfaction 
during OR to CSICU transfers. The SHP was developed after consulting with providers from anesthesia, surgery, ICU staff, and other disciplines normally involved in the perioperative environment, and laminated checklists were placed above each patient's ICU bed and given to providers as pocket-sized versions. Two and a half months was spent educating staff on how to utilize the newly designed SHP by using orientation handoffs, and the sequence of the report was as follows: the transfer of equipment, the transfer of information (order not specified), a period allowed for questions, and conclusion of report. All providers were to be present at the report and no steps were to occur simultaneously. Thirty handovers were observed before and after SHP implementation, and a total of 178 and 138 anonymous Likert-scale satisfaction surveys were completed by ICU RNs, ICU providers, surgery, and anesthesia providers before and after SHP application, respectively. Statistically significant improvements (with $\mathrm{p}<0.05$ ) included OR staff satisfaction with the new handover $(\mathrm{p}=0.001), \mathrm{RN}(\mathrm{p}=0.023)$ and $\mathrm{OR}$ staff $(\mathrm{p}=0.008)$ satisfaction with the ability to hear the report, OR staff satisfaction with smoothness of physical transfer ( $\mathrm{p}=0.001)$, OR staff satisfaction with clarity of beginning and end of report $(\mathrm{p}=0.021)$, and $\mathrm{RN}$ satisfaction with receiving anticipatory guidance $(\mathrm{p}=0.004)$. It should be noted that all survey respondent satisfaction scores improved in every category, but the above listed results were the only statistically significant satisfaction outcomes.

Segall et al. (2016) completed a QI observational study at a Durham Veterans Affairs (VA) Medical Center SICU to assess the impact of a redesigned SHP on OR to ICU handoff quality. Pre-implementation observations (49 total), interviews (mostly SICU and OR staff), focus groups, and surveys were used to establish a new SHP, and the newly established SHP was then revised after simulations were conducted to practice SHP-driven handovers. After successful simulations were completed using the finalized SHP, 49 post-implementation 
observations were observed. The SHP was posted in all ICU rooms, and the procedure proceeded as follows: patient monitor transferred, anesthesia and surgery alternate using situation, background, assessment, report aid - Situation-Background-Assessment-Recommendations (SBAR), all members ask questions and express concerns, and then anesthesia concludes. Interruptions were discouraged and the presence of surgery, anesthesia, and an ICU RN were encouraged. The study was unique because it collected surveys three years after implementation from 56 providers using a 5-point Likert-scale survey with questions pertaining to pre- versus post-SHP introduction. The only result that included a $p$-value (with $\mathrm{p}<0.05$ suggesting statistical significance) was improved provider satisfaction scores with the SHP compared to pre-SHP $(\mathrm{p}<0.0001)$. A bar graph was included showing improved satisfaction scores for all survey questions, but no other specific results were included.

Van Der Walt et al. (2016) accomplished an observational QI study in a large South African hospital cardiac ICU assessing provider satisfaction surveys associated with pre- and post-SHP implementation. A facility-specific SHP was developed by modifying an undisclosed United States SHP Likert-scale survey that focused on reducing interruptions and promoting the presence of OR staff and ICU RNs. SHP training was completed through presentations, visual aids, and booklets provided in the cardiac ICU and practice handovers led by researchers over a two-month span. A total of 30 handovers were observed after implementation. The progression of the SHP involved the following: anesthesia report initiated with time at the end for questions, surgery report initiated (and other OR staff if necessary) with questions allowed, and then the report was terminated. Post-implementation Likert-scale surveys were provided to surgeons, anesthesia providers, and ICU RNs, and survey result significance values were set at $p<0.05$. A total of nine questions were asked in the survey, and a list of total results may be seen in Table 1 
(see Appendix A). Some survey results with statistically significant improvements included RN and anesthesia satisfaction with surgery and anesthesia reports, the ability to hear the report, and information about potential patient problems and guidance on how to address the problems. Surgery survey results showed a statistically significant improvement in the satisfaction of the newly implemented SHP.

Lane-Fall et al. (2020) conducted a two-site pre/post-observational SHP implementation study at two separate Philadelphia academic tertiary hospital ICUs. The SHP was synthesized based on OR and ICU staff interviews and focus groups, and once finalized SHP education was achieved using posters and staff meetings. The SHP was organized in the following manner: ICU RN and physician, anesthesia, and surgery huddle, surgery gives report, anesthesia gives report, immediate concerns stated, focused exam of patient performed, questions asked, and report ends. Between the two sites, 68 pre-intervention and 97 post-intervention handovers were observed, and pre/post-satisfaction surveys were provided to an unspecified number of clinicians. One statistically significant $(\mathrm{p}<0.05)$ survey result included decreased trouble with finding appropriate clinicians for handover $(\mathrm{p}<0.001)$. Other statistics included the frequency of clinicians agreeing the new SHP was acceptable (89.5\%), the frequency agreeing the SHP made patient care better or much better (68.7\%), and the frequency agreeing the SHP made patient care worse or much worse $(0 \%)$.

Gleicher et al. (2017) executed a QI observational study in a cardiovascular ICU (CVICU) at a tertiary hospital to assess the impact of a SHP intervention by using postintervention satisfaction surveys. The SHP order was as follows: patient attached to ventilator, formal timeout to begin report, introductions from each handover participant, surgeon reports, anesthesia reports, time allotted for questions, and then report concludes. Key events targeted for 
improvement included improved information transfer, decreased interruptions, and the presence of OR staff and ICU patient recipients. The SHP was developed by physicians and nurses and incorporated input from literature reviews, surgeons, ICU RNs, and anesthesia members. The SHP was revised throughout a 4-month implementation period in order to improve adherence and actively incorporate feedback. Six pre-SHP and 31 post-SHP were observed in total for the study, and 36 total nurses, anesthesia members, and ICU physicians completed post-SHP satisfaction surveys. Frequency values for survey results included $91 \%$ agreement that the new SHP improved information quality transfer, 91\% agreement that the new SHP improved OR and CVICU staff teamwork, 97\% agreement that the SHP was a valuable addition to the cardiac surgery unit, and 3\% agreement that the new SHP interfered with clinicians' ability to provide timely patient focused care.

\section{Literature Review Synthesis}

Each study used similar methods to develop SHPs, chose sites with no existing OR to ICU patient handover report standardization, and utilized similar methods to educate handover staff before SHP implementation. In each study, SHPs were created after extensive literature reviews and suggestions from standard handover staff, such as surgeons, anesthesia providers, and ICU RNs and physicians (Gleicher et al., 2017; Krimminger et al., 2018; Lane-Fall et al., 2020; Petrovic et al., 2012; Segall et al., 2016; Talley et al., 2019; Van Der Walt et al., 2016). Studies conducted by Lane-Fall et al. (2020), Petrovic et al. (2012), Talley et al. (2019), and Van Der Walt et al. (2016) educated staff on SHP utilization through staff meetings, orientation handoffs, team huddles, presentations, and/or emails. Some unique SHP education techniques included Segall et al. (2016) using simulations and Gleicher et al. (2017) actively revising and 
teaching staff while conducting real handovers. Krimminger et al. (2018) did not mention educational techniques utilized.

Every project performed a similar number of observations after SHP employment, placed finalized SHPs in similar locations, and structured protocols similarly across studies. The number of handovers using newly developed SHPs per study ranged from 30-97, except for Talley et al. (2019) which made no mention of handovers observed (Gleicher et al., 2017; Krimminger et al., 2018; Lane-Fall et al., 2020; Petrovic et al., 2012; Segall et al., 2016; Van Der Walt et al., 2016). All journals mentioned laminated SHPs were placed above ICU beds, but the Krimminger et al. (2018) and Petrovic et al. (2012) studies declared that they also provided laminated pocket-sized SHPs to all handover staff (Gleicher et al., 2017; Lane-Fall et al., 2020; Segall et al., 2016; Talley et al., 2019; Van Der Walt et al., 2016). All studies' SHPs emphasized the importance of conducting the report in the presence of anesthesia and surgery members, ICU RNs, and ICU clinicians, reducing distractions and interruptions, limiting parallel conversations, initiating report after patient synchronization with the ICU monitor, and concluding the report only after all staff questions are answered. Some SHP variations included: Krimminger et al. (2018) and Talley et al. (2019) required the additional presence of a respiratory therapist (RT), Krimminger et al. (2018), Segall et al. (2016), and Van Der Walt et al. (2016) had an anesthesia member initiate the report, Gleicher et al. (2017) and Lane-Fall et al. (2020) had reports led by a surgery member, and Petrovic et al. (2012) and Talley et al. (2019) had ICU clinicians begin the report. Gleicher et al. (2017) was unique in that it had an Anesthesia Assistant monitor the patient while report was conducted.

Each study measured handover staff satisfaction scores similarly by using Likert-scales, but questions asked in each survey, members who completed surveys, and when surveys were 
offered differed across studies. Although the articles differed in some of the outcomes evaluated, all articles included outcomes measuring staff satisfaction after SHP implementation (which is the major outcome of interest for this project) and every study's results indicated an improved staff satisfaction score for at least one handover question. Krimminger et al. (2018) and Petrovic et al. (2012) compared anesthesia, surgery, and RN satisfaction scores from before and after SHP enactment while Van Der Walt et al. (2016) surveyed the same population only after implementation. Some statistically significant findings (defined as $\mathrm{p}<0.05$ ) from the articles included improved satisfaction from all staff with the new SHPs, decreased interruptions, increased ability to hear the report, improved communication about when the report begins and ends, and enhanced anticipatory guidance for RNs. Talley et al. (2019), which compared pre- and post-SHP RN satisfaction scores, had similar results but additionally revealed improved RN satisfaction with feeling included during report and not feeling too busy to receive a formal report.

The other three studies also disclosed improved satisfaction scores but had a few distinct variables. Segall et al. (2016) was a unique study which assessed satisfaction survey outcomes three years after initial SHP implementation (while the other six studies assessed outcomes immediately after implementation), and results indicated an improved staff satisfaction with handovers after SHP introduction. The Lane-Fall et al. (2020) results were based solely on postSHP satisfaction scores. Although which clinicians completed satisfaction surveys was not cited, results exposed increased staff satisfaction with handovers and an agreement that patient care improved after SHP deployment. Gleicher et al. (2017) measured post-SHP satisfaction results from the same staff as the other six studies but also included ICU physicians. All of those surveyed reported an increased satisfaction with handover staff teamwork and the value of the 
addition of a SHP. In conclusion, all seven studies included in the literature synthesis presented results indicating improved staff satisfaction with OR to ICU patient handovers after SHP implementation.

\section{Purpose Statement}

The purpose of the project was: 1) to implement a standardized handover process checklist to be used by OR and SICU staff during bedside transfers once patients arrive to their assigned post-operative room, and 2) to improve handover staff satisfaction and perceptions with the handover process by comparing pre- and post-SHP checklist utilization survey scores (see Figure 1 contains specific survey questions (see Appendix B) and Figure 2 includes the checklist to be used during handovers (see Appendix C).

\section{Rationale}

Theoretical frameworks are sometimes used as tools to assist researchers and practitioners with project development ideas. They help to identify and describe inefficiencies within organizations, develop interventions to address the identified inadequacies, and create methods to evaluate project outcomes and effectiveness. Two theoretical frameworks were reviewed and applied to aid in standardizing OR to SICU patient handovers.

\section{Quality Caring Model}

The project's site uses the Quality Caring Model to help guide evidence-based nursing practice within its organization. The foundation of the Quality Caring Model is the formation of professional relationships between nurses and patients so that interventions performed during interactions leaves patients feeling “cared for" (Duffy \& Hoskins, 2003). The project's focus was to ultimately improve patient care and outcomes once they arrive to and temporarily remain in the ICU by bettering interprofessional communication and relationships during patient 
handovers. The project follows the Quality Care Model because improving the communication of critical information regarding post-operative patients ensures nurses and other interprofessional caregivers will provide appropriate care targeting unique patient needs identified during the handover process. Utilizing a SHP will inspire the formation of professional relationships between patients and nurses (CRNAs, ICU RNs and NPs) and other caregivers because it allows patients to realize their safety and wellness are prioritized during their vulnerable post-operative state.

\section{Focus, Analyze, Develop, Execute (FADE) Model}

The FADE model is also an appropriate theoretical framework that was used to guide the Doctor of Nursing Practice (DNP) quality improvement project evaluating the effectiveness of implementing a SHP for patient transfers from the OR to a SICU. According to the United States Department of Health and Human Services' Health Resources and Services Administration (HRSA, 2011), the FADE model is a framework used by healthcare organizations to implement and evaluate quality improvement endeavors. The FADE "focus" aspect is that the project's site has no SHP for when patients arrive to the SICU from the OR, and thus there is a lack of consistency in the handover report. Report quality often suffers due to distractions, interruptions, and lack of handover staff presence.

Furthermore, the FADE model "analyze" step was primarily based on handover staff satisfaction scores (ICU nurses, SICU surgeons, and anesthesia providers) prior to implementation of the SHP. An anonymous online survey was emailed to handover staff to assess attitudes and perceptions regarding pre-project handover practices via Likert-scale questions and an open-ended text box to voice dissatisfactions and recommendations for improvement. The project focused on the perceptions and satisfaction of three major surgical 
services that interact with SICU patients and staff: general surgery, orthopedics, and trauma. The "development" phase of the FADE model entailed the synthesis of the SHP and an educational email detailing appropriate checklist use. The goal was to develop and implement a SHP for interprofessional teams to streamline and improve the handover report and improve the report process, overall communication, and staff satisfaction and perceptions.

Additionally, the FADE model "execute" stage involved placing laminated SHP visual cues in each patient's room. Commitment to SHP utilization was encouraged by SICU administrative staff, charge nurses, and bedside nurses receiving patients from the OR. Based on similar studies' sample sizes, 45 handovers utilizing the new SHP sufficed before assessing postimplementation staff perceptions and satisfaction. After sufficient SHP employment, the same pre-SHP surveys were emailed to handover staff to assess staff opinions and satisfaction with the newly developed SHP. The execution stage lasted two months. The FADE model often concludes with an evaluation phase, so a statistical analysis was performed to measure for significant improvements in staff satisfaction survey scores from pre- to post-SHP implementation.

\section{Specific Aims}

The aim of the project was to evaluate the impact of a SHP on anesthesia, surgery, and RN perceptions and satisfaction regarding handovers of post-operative patients to the SICU. The Centers for Disease Control and Prevention (CDC, 2017) released a guide in 2017 on how to write realistic and achievable goals, referred to as SMART goals. The acronym stands for specific, measurable, achievable, realistic, and time-phased goals. Following the SMART goals outline, the project's objectives were to show a statistically significant improvement (p-value less than 0.05) in 6 survey questions (see Appendix B) when comparing post-SHP 
implementation survey scores to pre-implementation survey scores after 45 handovers and two months of using the SHP.

Specific project aims included improvements in handover staff satisfaction with the handover bedside report, perceived clarity of when the report begins and ends, perceived reduction in interruptions, perceived increase in the ability to hear the entire report, satisfaction with the communication of all critical information concerning the patient and the procedure, and the presence of all pertinent interprofessional team members during the bedside report. A literature-based checklist was devised to achieve the specific aims after utilizing it at the project's site. Likert scale surveys were designed explicitly to measure whether the specific aims were satisfied after two months of checklist enactment.

\section{Methods}

\section{Context}

The project's site is a Level 1-designated trauma/surgical ICU (SICU) that treats approximately 3,000 patients yearly and employs over 10 surgical specialty teams (WVU Health System, 2020). The population of interest included interprofessional team members who participate in the post-operative SICU handover process. The project's implementation focused on the bedside handover that occurs within the SICU. The project's SHP emphasized the presence of a surgery member, anesthesia provider, and admitting RN at the patient's bedside to appropriately conduct the handover report and utilize the project's checklist. The surgery team

member discussed procedural information and expected patient needs. The anesthesia provider discussed hemodynamics, airway and breathing, medications and line access, and anticipated patient needs. The admitting RN posed pertinent nursing questions and clarified any missing information. The three professions involved in the handover process were also provided 
satisfaction and perception surveys before and after project execution to evaluate the impact of SHP implementation.

\section{Intervention}

Patient handovers from the OR to the ICU are often hectic engagements involving the transfer of equipment, continuously infusing medications, and critical patient information. Information pertaining to surgical interventions, hemodynamic and airway management, equipment regulation, intraoperative complications, and post-operative stabilization strategies exemplify critical information that must be communicated to ensure safe transfer of care. Using a SHP has exhibited reductions in mistakes and miscommunication during such demanding interactions (Krimminger et al., 2018). Because the project's site lacks a formal bedside report once patients arrive to their post-operative room, the project's main purpose was to use a literature-based bedside report to guide handover communication to ensure clear and concise patient information was transferred from OR staff to the admitting RNs and thus align with the project's specific aims.

The project sequence was as follows: pre-execution surveys, educational period, project implementation, and post-project surveys. Upon institutional review board (IRB) approval, the pre-execution Likert scale surveys were sent to the emails of anesthesia providers, SICU surgeons from three surgical specialties, and SICU RNs before project implementation. The surveys, created using Qualtrics (2020), were used to assess staff satisfaction and perceptions about specific features surrounding present handover procedures (see Appendix B). Surveys were anonymous, and a statement regarding voluntary participation was included. The survey results served as a baseline for post-project comparison, enabling statistical analysis. The first month of project implementation entailed survey collection and analysis as well as education for 
survey respondents. Education was provided to handover staff via emails and during routine team huddles and entailed familiarization with the checklist. An informational email with an attached checklist was also sent to the same handover staff and included pre-project surveys (see Appendix G).

Based on analogous study designs mentioned in the literature review and synthesis, the project continued for two months, and 45 total handovers used the newly developed SHP checklist. It was critical that an anesthesia member, surgery member, and the admitting $\mathrm{RN}$ were in attendance for bedside handover from the OR to the SICU. Emphasis was placed on minimization of distractions and interruptions during handover report, the absence of parallel conversations between handover participants, and the use of the newly developed checklist to guide the report sequence. The RN assuming care of the patient was encouraged to ask questions at the end of the surgery and anesthesia portions of the report to ensure clarity. After two months of SHP usage, post-project surveys were emailed to the same handover staff that completed preproject surveys to assess satisfaction and perceptions of handovers after applying the SHP. A Mann-Whitney U Test was conducted to determine if pre- and post-project survey comparison results were statistically significant. The test was chosen because it allows the comparison of two sample means collected from the same population sample. The test was also chosen due to the incapacity to link individuals' pre-project and post-project survey results to maintain anonymity, the containment of ordinal variables within the surveys, and the inability to reach the survey quota of 34 per each group.

\section{Plan to Address Gaps in Evidence}

Two main gaps in evidence exist for the project in relation to survey questions and checklist utilization. A standardized survey was not available to ask staff questions about 
handover perceptions, so a synthesized survey based on pertinent literature was created and used for the project. Similarly, a universal OR to ICU SHP checklist has not been developed, so a checklist based on several relevant previous studies' checklists (found in the literature review and synthesis section) and the specific needs of the project implementation site was developed for the project (see Appendix C).

\section{Benchmarks}

An ideal benchmark to compare project results has not been identified. Although similar studies and project designs have been conducted to assess staff satisfaction with newly implemented SHPs, no benchmarks have been established by reputable organizations, such as the Centers for Medicare and Medicaid Services or the Agency for Healthcare Research and Quality, in terms of OR to ICU SHPs. Therefore, a statistically significant improvement in staff perceptions and satisfaction with the handover process was sought after a SHP checklist was introduced.

\section{Congruence With the Organization's Strategic Plan}

The organization of interest's mission statement is "To improve the health of West Virginians and all we serve through excellence in patient care, research, and education" (WVU Medicine, 2020). The project's intent aligned with the organization's mission statement in all three areas. The study was founded on extensive and thorough research which supports the use of a SHP to improve staff communication and satisfaction, thus leading to improved patient care and the health of all patients cared for by the organization's caregivers. Educating handover staff about the benefits and appropriate use of SHP checklists further supported the organization's vision of improving patient health through excellence in education. 
The organization's nursing division strategic plan for 2020-2022 had two goals that correlate with the project's intentions: "empower nursing care through communication and interprofessional collaboration" and "influence patient care by standardizing practice across the WVUH Medicine System" (personal communication, July 28, 2020). By standardizing the postoperative handover report, SICU nurses were able to fully engage in report and collaborate with OR staff to identify and concur on immediate patient needs. Furthermore, patient care may have improved by eliminating communication breakdowns during report through handover standardization so that critical and pertinent patient information was transferred appropriately and efficiently.

\section{Needs Assessment}

In addition to theoretical frameworks, a needs assessment is a valuable tool to help guide project development. The needs assessment is similar to the "analyze" stage in the FADE model because it helps to define what the problem is, identifies the variables and requirements necessitated to fix the problem, and explains why fixing the problem is important to an organization (Bonnel \& Smith, 2014). As mentioned earlier, the problem focus for the project was the lack of a consistent and methodical handover process when post-operative patients arrive to the SICU. Consequences of patient transfers without a SHP often include miscommunication, exclusion of critical information, and poor staff satisfaction (Segall et al., 2011). The combination of literature reviews and personal experience aided in the construction of a unitspecific SHP.

\section{Strengths, Weaknesses, Opportunities, Threats (SWOT) Analysis}

A SWOT analysis is a tool commonly used by individuals and teams to evaluate an organization's readiness for the introduction of a new project or change in the organization's 
operations, so an analysis was conducted prior to project implementation (Mind Tools, 2019).

Strengths for the project included handover staff interest and perceived value of project introduction at the intended site and the hospital's "Magnet" designation which encourages quality improvement projects and evidence-based practice. Possible project weaknesses included the potential lack of survey participation and the culture within the hospital's SICU where nurses feel obligated to complete tasks when patients initially arrive from surgery instead of focusing on receiving report. Opportunities included the potential for a permanent change in the handover process and improved interprofessional team collaboration and communication among handover staff. Potential threats to project implementation included inadequate face-to-face education due to coronavirus 2019 (COVID-19) and the maintenance of surgeon and anesthesia "buy-in" due to the hospital's high acuity environment.

\section{Budget Plan}

Project costs were minimal and were mostly in the form of "time costs," but personal funds were required to produce educational material and copies of SHP checklists. Brief checklist education involving checklist familiarization was provided to handover staff during routine team huddles. Surveys and educational material were also sent to staff organizational email addresses to be completed while staff are at work. Expected survey completion time was 25 minutes and the time needed for in-person checklist familiarization and informational email comprehension was 5-20 minutes. Since the checklists were intended to be used during normal periods of patient handovers from the OR to the SICU, little to no extra time was anticipated to be spent during handovers. A total of 14 checklists were copied and laminated using a local business' printer and supplies and placed in each SICU patient room. Examine Table 2 for more detailed project costs (see Appendix D). 


\section{Personnel and Technology}

The SHP required minimal investment from the organization in terms of both time and capital, but a few potential barriers were considered. Basic project needs included access to staff emails and time for handover staff to complete relatively short surveys and receive education concerning SHP utilization. Surveys and education required an estimated 5-20 minutes of staff time when available. Staff participation was also key, and that's why stakeholder identification and communication was valuable to project development progression. The SICU manager, a key project stakeholder, approved the project for unit implementation (see Appendix E), and informative emails were also disseminated to the department heads of anesthesia and three surgery services. In addition to SHP placement in every SICU patient room, SICU charge and acuity nurses were recruited to encourage SHP use because they often aid bedside receiving nurses with the OR to ICU patient handover process.

\section{Sustainability of the Proposed Project}

The goal of the project was not only to enhance patient care through improved communication and staff satisfaction, but also to establish a lasting practice change. There was no foreseeable negative impact on SICU's handover workflow during project implementation because of the lack of current handover uniformity. In fact, it was anticipated that SHP use would improve handover workflow by decreasing distractions and interruptions, increasing staff presence and role identification, and improving the quality and conciseness of information shared. The project's intention was to assist the site's OR to SICU patient handover process so that it evolves into an exemplar procedure that other healthcare organizations strive to mimic. Moreover, consistent use of handovers may lead to future projects designed to measure specific patient outcomes related to handover report quality. 


\section{Evidence of Key Site Support}

The primary stakeholder was the hospital's SICU manager, and she provided written approval for the project's implementation after IRB approval (see Appendix E). SICU nurses were also prepared to support SHP checklist adherence during post-operative handovers upon project execution. SICU charge nurses and acuity nurses also aided in patient handovers to allow bedside nurses to engage in handover report. OR staff were also encouraged to use handover checklists after reading informational emails emphasizing the checklist's value and appropriate usage.

\section{Project Timeline}

The project began in April of 2021 with one month of pre-SHP survey dissemination and collection and an informational email sent to handover staff. The following two months were spent utilizing the SHP so that 45 handovers were accomplished using the newly developed checklist. The final two months involved conducting post-project surveys and collecting data to perform statistical analyses. For specific project dates, refer to Table 3 (see Appendix F).

\section{Study of the Intervention}

The implementation site's ICU manager, charge nurses, and acuity nurses encouraged usage of the SHP checklist at each post-operative bedside patient handover involving orthopedic, general surgery, and trauma service patients. Charge nurses were contacted via text messages on a weekly basis to ensure the project's checklist was being utilized. Regular communications were maintained with unit charge nurses to ensure the three surgical specialties of interest, anesthesia providers, and receiving nurses were utilizing checklists because charge nurses track every patient within the unit and their associated nurses and surgical care teams. This also allowed tracking of the number of handovers utilizing the SHP so that the goal of 45 handovers was 
satisfied. Ongoing communication allowed elucidation of any checklist questions or enactment obstacles and supported efficient usage of the SHP checklist, ultimately leading to the fulfillment of the project's handover quota.

Charge, acuity, and neighboring nurses and clinical associates regularly aid bedside nurses with patient transfer tasks during handovers, such as connecting and organizing all the patient's equipment and devices, so maintaining the practice during the study allowed bedside receiving nurses to immediately begin bedside report with the OR surgeon and anesthesia provider while patients were tended to by competent staff. Allowing bedside nurses to focus on handover reports when the patient immediately arrived from the OR, rather than focusing on patient tasks, permitted a timely, fluid, and interruption-free handover report to be conducted while using the SHP checklist.

Each finished survey was assessed for completeness, particularly the six questions to be used for statistical comparison between pre- and post-implementation results. Qualtrics (2020) allowed immediate access to the survey completion database, so survey results were easily accessible at any time. Using G. Power, assuming $\alpha=0.05$, Power $=1-\beta=0.80$, and Cohen's d $=0.50$ (moderate effect), 34 surveys from each profession were recommended to ensure valid statistical tests were able to be performed. Post-project surveys were sent to the same staff who received pre-project survey emails, and a disclaimer was included to inform recipients to complete surveys only if they completed a pre-project survey and utilized the SHP checklist. Since data was collected via qualitative surveys, as opposed to direct handover observations or other methods at risk for observation bias, accuracy was not a major concern. A statistician was also consulted to ensure appropriate and accurate statistical calculations were completed. 


\section{Evaluation Plan}

The project used a five-point, Likert scale survey emailed to surgeons, anesthesia providers, and ICU nurses to assess the impact of a SHP checklist on OR and SICU staff satisfaction and perceptions concerning the handover process. Qualtrics (2020) was chosen to create surveys because it assigns point values to Likert-scale survey answers so that qualitative questions can be analyzed using quantitative statistical methods. Baseline handover perceptions were determined via surveys completed prior to project-implementation, and the exact same surveys were conducted after two months of SHP checklist utilization to establish whether the post-project outcomes were due to the newly established SHP. Figure 1 details the specific survey questions (see Appendix B).

The anonymous Likert scale surveys consisted of a profession identification question, six closed-ended responses, and one open-ended response. The closed-ended questions were each assigned a 5-point rating and allowed handover staff to answer satisfaction and perception questions concerning handover processes before and after SHP checklist usage. The single openended question permitted handover staff to express concerns or considerations for improvements to the handover procedures before and after project enactment. No universal, validated survey was found during the literature review that could be used specifically for the project's intentions. However, project surveys exhibited reliability and validity because they were synthesized from similar studies' surveys.

\section{Measures}

Surveys with Likert scale questions were chosen to study project methods and intervention outcomes because Likert scales, particularly five-point scales, are among the most widely studied and used survey types to assess attitudes and perceptions (Lavrakas, 2008). 
According to the CDC (2012), a Likert scale is defined as "an ordered scale from which respondents choose one option that best aligns with their view. It is often used to measure respondents' attitudes by asking the extent to which they agree or disagree with a particular question or statement." For a Likert scale to meet validity and reliability requirements, four criteria must be met: questions are declarative statements, answers are ordinal and continual (i.e., strongly disagree to strongly agree), there are equal positive and negative response choices, and numeric values are assigned to each response. Six Likert questions were developed for the project's surveys following the aforementioned criteria, and each question had five choices with a number value assigned to each response for later statistical analysis (strongly disagree $=1$, somewhat disagree $=2$, neither agree or disagree $=3$, somewhat agree $=4$, and strongly agree $=$ $5)$.

Ongoing survey assessment was achieved using the Qualtrics (2020) online survey database, which contributed to the efficiency, success, and zero budgetary requirement of the project's outcome measurements. Qualtrics (2020) proved efficient by sending alert notifications to the researcher immediately after anonymous surveys were completed by handover staff participants. Qualtrics' (2020) efficiency was also displayed by its well-organized and very detailed statistical analyses provided to researchers. The user-friendly surveys and detailed and easily navigable survey response data contributed to the success of the project's implementation and data collection and analysis. Qualtrics (2020) also required no financial investment from researchers due to its free services provided to university students. Lastly, Qualtrics (2020) survey participation and responses were able to be assessed for completeness and accuracy by any device with internet capabilities, which also contributed to the project's efficiency and success regarding data collection and analysis. 


\section{Analysis}

Authenticated statistical evaluation software and a statistics expert were consulted to analyze and interpret collected project data. Pre-project and post-project surveys were not linked to each individual completing the surveys in order to maintain anonymity, the surveys contained ordinal variables, and the survey quota of 34 per each group was not attained; therefore, a MannWhitney U test was used to draw inferences between pre- and post-project survey data. International Business Machine's (IBM, 2020) Statistical Product and Service Solutions (SPSS), a validated statistical analysis software program, was employed to perform the project's quantitative statistical analyses. Surveys were qualitatively assessed for participation, completeness, and responses to the qualitative question found on each survey. Time did not have a significant effect on variation within the data because the time interval for project completion was five months.

\section{Ethical Considerations}

Compliance with all the organization's ethical standards and principles to protect patients' rights and safety was maintained through all stages of the project. Approval of the project's proposal was obtained from the organization's IRB before project implementation. The project did not access patient health history or data. Emails sent to handover staff included a disclaimer informing recipients that survey completion was entirely voluntary, and that anonymity would be maintained for each survey participant. Qualtrics (2020) does not collect or store personally identifiable information or data from survey participants, so anonymity was maintained throughout the project's entirety. Patients were expected to benefit from the project's design while anticipated risks were minimal to none. There were no financial or other conflicts of interest concerning the project and its implementation site or project researcher. 


\section{Results}

\section{Intervention Steps and Evolution Over Time}

After one month of education provided to handover staff concerning SHP checklist usage and survey collection, the following two months encompassed staff usage of the project's checklist. Contact with SICU charge RNs was maintained weekly to gather data about the frequency of checklist usage and the surgery services involved. The goal of 30 to 60 handovers using the project's checklist was met during the two-month period and no major modifications were required during the interventions. Post-implementation surveys were collected for one month and data was analyzed for two months upon project completion. Proposed project dates were slightly altered while awaiting IRB approval, and Table 3 reflects accurate project timelines (see Appendix F).

\section{Measures and Outcomes}

The project's SHP checklist was utilized 45 times over two months during handovers between OR staff and SICU RNs while 52 and 47 total surveys were completed by handover staff one month before and after project execution, respectively. The following number of handovers per surgery service were completed using the SHP checklist: 23 general surgery, 12 trauma blue, and 10 orthopedic. The number of Likert scale surveys completed by handover staff prior to project implementation included 23 by SICU RNs, 19 by anesthesia providers, and ten by surgery team members. After project implementation, Likert scale surveys were completed by 21 SICU RNs, 18 anesthesia providers, and 8 surgery team members.

The project's surveys evaluated handover staff perceptions and satisfaction regarding patient handover reports before and after SHP implementation. Regarding SICU RNs, two of the six Likert scale survey questions revealed statistically significant results after the project's 
implementation while four of the six questions did not. A statistically significant increase (p $<0.05$ ) was found in response to the question "Overall, I am satisfied with the quality of the OR to SICU bedside patient handover report process" when comparing the pre-project and postproject surveys' mean values ( 2.91 before to 3.57 after; $\mathrm{p}=0.041$ ). SICU $\mathrm{RN}$ surveys also demonstrated a statistically significant decrease in response to the question "I am often unable to find or identify the appropriate staff member(s) needed to conduct a thorough bedside handover report (receiving bedside nurse, surgery member, or anesthesia provider)" after comparing survey means ( 3.74 before to 3.00 after; $p=0.022$ ). Of the remaining four SICU RN survey question, results showed improved mean scores but no statistically significant increase or decrease in responses after project intervention completion. Detailed results may be found in Table 4 (see Appendix H).

Anesthesia survey response mean comparisons also revealed varying statistically significant outcomes. Anesthesia survey responses to the question "Overall, I am satisfied with the quality of the OR to SICU bedside patient handover report process" indicated a statistically significant increase between before-and-after project survey mean values ( 3.42 before to 4.11 after; $\mathrm{p}=0.022$ ). Anesthesia surveys also displayed a statistically significant increase between pre-survey and post-survey mean values ( 3.79 before to 4.33 after; $\mathrm{p}=0.024)$ in response to the question "I am satisfied with the information that is communicated concerning the patient and the procedure during the bedside handover report." Anesthesia survey outcomes for the remaining four questions exhibited improved mean values but no statistically significant results. Comprehensive findings may be found in Table 5 (see Appendix I).

Mean comparisons of surgery team member surveys also divulged statistically significant results to two questions. A statistically significant decrease was noted between pre-project and 
post-project survey means ( 4.30 before to 2.75 after; $p=0.023$ ) according to surgery team members' responses to the question "Interruptions frequently impair the bedside handover report." A statistically significant decrease was also realized between survey means (4.50 before to 2.88 after; $p=0.028$ ) in response to the question "I am often unable to find or identify the appropriate staff member(s) needed to conduct a thorough bedside handover report (receiving bedside nurse, surgery member, or anesthesia provider)". Other results displayed improved scores in all but one question but no statistically significant differences when comparing survey mean values. Complete findings may be found in Table 6 (see Appendix J).

Surveys also included a section for responders to provide comments or suggestions in respect to patient handovers between OR and SICU staff before and after project enactment. Example pre-survey responses included "I think identifying who is giving report/receiving report from the get go will be beneficial", "Have the CRNA or anesthesia provider call report prior to arriving instead of the OR RN", "It's often difficult to find the bedside nurse", and "Too many people in the room at once. It's difficult finding who to give report to". Some post-survey replies included "I liked using the report sheet when I did use it. Sometimes I was too busy and forgot", "I was too busy to ask for a good report from the OR", "The report sheet worked well when nurses used it. There was inconsistency with using it though", and "It was helpful when the bedside nurse asked for a report”. All responses may be found in Table 6 (see Appendix J).

\section{Unintended Consequences and Missing Data}

The project's intervention stage encountered a few unanticipated issues during its twomonth operation. One difficulty included inconsistency with checklist usage by all services involved with OR to SICU patient handovers. An additional complication was the failure to meet each service's 34 survey sample quota. The project also had missing data in terms of five pre- 
survey participants failing to complete post-project surveys. No unexpected costs were noted in association with the interventions.

\section{Discussion}

\section{Summary}

Some key findings in relation to the project's problem statement and specific aims were exposed after the SHP checklist intervention. Problem statement factors addressed included a significant improvement in patient information communication and staff satisfaction with the overall patient handover procedure and a significant reduction in report interruptions and handover team member absence. The project's specific aims were to significantly improve staff satisfaction and perceptions during OR to SICU patient handovers after standardizing the handover report. Although not all results were statistically significant, all services' survey results showed improvements in almost all six categories except for the surgery services' satisfaction with the information communicated during handover (satisfaction remained high both before and after the intervention).

Strengths of the project included simplified interventions, navigable statistical data, positive participant comments, and a foundation for potential future projects. The project's concise checklist and surveys required minimal additional "time-costs" from participating staff working at a high acuity facility. Data collection and analysis were also relatively simple and uncomplicated while still allowing the interpretation of statistical significance. Another strength included positive reviews mentioned in survey comments when the checklist was utilized during report. Lastly, encouraging checklist usage beyond the project's termination may allow future researchers to measure other variables of interest (i.e., handover duration or patient specific factors such as length-of-stay, morbidity, etc.). 


\section{Interpretation}

Some associations between the intervention and outcomes may be inferred after analysis of the results. Because mean survey scores improved in almost all questions across the handover services, it is likely that the project's checklist implementation improved staff satisfaction and perceptions with patient handovers. Some more specific findings included RNs and surgery members felt they were more able to find handover staff for the report initiation. This may be due to the checklist recommendation of identifying all handover members prior to commencing the report. Other pertinent findings included anesthesia participants' enhanced satisfaction with patient information transferred to SICU staff. This finding could correlate with the ICU-specific information suggested by the checklist to be used by anesthesia contributors. Another key finding included surgery members' perceptions that report interruptions were reduced. This may have been associated with the checklist's proposal of "huddling up" prior to report initiation and minimizing interruptions unless emergencies arise.

The post-project surveys also revealed qualitative outcomes in the form of participant comments, specifically related to checklist quality and its utilization. A common theme found among all handover staff services was satisfaction with the checklist when it was used during report. Staff enjoyed identification of handover contributors, information communicated, and overall handover quality. However, several comments from all services stated that checklist usage was inconsistent during the intervention stage. Most such comments mentioned checklist forfeitures due to staff being too busy to conduct a formal report.

A literature review and synthesis concerning OR to ICU handovers revealed similar findings to the project's outcomes. Among the seven relevant articles with similar project designs, all seven disclosed staff satisfaction improvements with handovers after a standardized 
report was introduced in organizations with no standardization in place. For example, Krimminger et al. (2018) followed checklist usage and survey comparisons between OR and cardiac ICU staff patient handovers. Overall handover report, information communicated, and distraction minimization satisfaction improved after checklist introduction. Findings also revealed staff felt too time-constrained to give a thorough report and/or immediately care for post-operative patients. Table 1 details more specific results from other studies (see Appendix A).

The project impacted the people and systems involved with the institution's handover procedures. The people mainly affected by the intervention were the participating RNs, surgery members, and anesthesia providers who used the SHP checklist during handovers. Results revealed a mostly positive impact on participant satisfaction with handovers after using the project's checklist, although usage was varying. The project's impact on patients transferred from the OR to the SICU was not observed during the project. The system impacted by the project was predominantly the handover process itself. By introducing a standardized checklist for handover reports, the hospital's traditional varying handover routines were subject to a more formalized, scripted, and organized structure when utilized.

Differences between observed and anticipated outcomes after two months of checklist usage may be due to several reasons. One cause may have been due to the variability of checklist usage by handover staff which could have decreased participants' confidence in the project's efficacy. A second explanation may have been handover staff resistance to changing a process they felt needed no alterations. Another likely reason may have been due to staff feeling too busy to engage in handover report because of the hospital's fast-paced environment. Lastly, less than 
anticipated survey participation limited the ability to evaluate all the facility's handover staff's perspectives.

Some opportunity costs and strategic trade-offs were also encountered during the intervention stage. One example included emailing surveys to staff instead of handing out physical surveys to be completed immediately after education sessions. Another was not incorporating the site's neurological ICU, which is considered a "sister-unit" to the SICU. An additional example was the lack of devising an electronic version of the checklist to be used by staff because all charting is completed electronically in the site's SICU.

\section{Limitations}

The study's limitations included its generalizability and factors affecting its internal validity. The project's SICU supported the intervention because the hospital encourages evidence-based practice and quality improvement projects. However, not all institutions and/or handover contributors may support a culture of change. For example, some hospital units prefer receiving handover reports via phone from OR RNs prior to the patient arriving to the unit rather than bedside report. Similarly, anesthesia, surgery, and/or RNs may be satisfied with current handover report procedures or information communicated and see no need for change. One such instance from the project was surgery survey results revealing high pre-project satisfaction with handover details and no subsequent increase in satisfaction after using the project's checklist.

Internal validity may have been limited due to less than expected survey participation and survey dissemination design. The project's design recommended 34 surveys per anesthesia, surgery, and RNs to improve statistical validity. Despite efforts to increase participation, such as multiple survey email reminders and in-person educational sessions, the quota was not attained, and statistical results were weakened. Although response rates were less than anticipated, a study 
by Safdar et al. (2016) found response rates to emailed surveys are typically low, averaging 20 to $30 \%$. Internal validity was also enfeebled due to the lack of linking each participant's pre-survey with their post-survey to maintain anonymity. To minimize the effects of not connecting pre- and post-project surveys, a Mann Whitney test was performed to strengthen the validity of the project's results.

\section{Conclusions}

An extensive literature review revealed the significant impact of SHPs on handover staff satisfaction and perceptions with bedside patient handovers from the OR to the ICU. Surveys completed by surgeons, anesthesia providers, and ICU RNs exposed a collective agreement that SHPs improve handover communication, staff presence, clarification of when reports begin and end, and report organization in addition to reducing interruptions and distractions during report. The application of a SHP bedside report checklist between OR and SICU staff at the project's hospital revealed statistically significant improvements in staff satisfaction and perceptions with the overall handover process, information communicated, and handover staff identification. Survey result comparisons also revealed improved anesthesia, RN, and surgery handover participants' satisfaction and perception with report clarity, audibility, and reduced interruptions.

The future sustainability and usefulness of the SHP checklist at the project's site depends on a few significant elements. Consistency in checklist usage could be increased by creating a team with a surgery, anesthesia, and $\mathrm{RN}$ representative who collaborate on adjustments to be made to the checklist and handover practices. The team might also encourage, monitor, and possibly require checklist usage, particularly by creating an electronic checklist required for charting purposes. Expansion of the checklist to other ICUs would also allow broadened perspectives from other services and unit staff. The measures mentioned to raise checklist 
sustainability and usefulness align with the organization's vision and nursing's strategic plan which encourages research, education, nurse empowerment, and standardization of care.

Identified facilitators and barriers during the projects execution also may impact the project's future sustainability at the facility. Facilitators included the organization's willingness to participate in QI projects and department heads' collaborative interest. Barriers included lack of formal meetings with large groups of anesthesiologists and surgery members due to COVID19 social distancing. Future key stakeholders that would likely increase project participation and ICU handover standardization include more attending surgery physicians, attending anesthesiologists, senior CRNAs, and senior neurological critical care unit and SICU RNs. A large, face-to-face meeting among the future stakeholders would amplify the identified facilitators, minimize barriers, and ultimately allow more handover collaboration.

A few recommendations may be made regarding the project's potential spread to other contexts, implications for future studies, and next step suggestions. In addition to standardizing handovers in other post-operative ICUs, report standardization may prove beneficial in other units where such practices are not in place. Report standardization promotes communication of key patient information between providers each time patient care is transferred while decreasing accidental omission of data. Future studies may focus more on quantitative outcomes, such as time spent conducting report or patient hospital length of stay, morbidity, and specific information communicated or omitted. Suggested next steps include increased handover staff collaboration and input, checklist review and adjustments, and more in-person informative meetings. 


\section{References}

Bonnel, W., \& Smith, K. V. (2014). Proposal writing for nursing capstones and clinical projects. Springer Publishing Company.

Canva. (2020). Design anything. https://www.canva.com/

Centers for Disease Control and Prevention. (2017). CDC coffee break: Using Likert scales in evaluation survey work. https://www.cdc.gov/dhdsp/pubs/docs/cb_february_14_2012.pdf

Centers for Disease Control and Prevention. (2017). Evaluation guide: Writing SMART objectives. https://www.cdc.gov/dhdsp/docs/smart_objectives.pdf

Duffy, J. R., \& Hoskins, L. M. (2003). The Quality-Caring Model: Blending dual paradigms. ANS. Advances in nursing science, 26(1), 77-88. https://doi.org/10.1097/00012272-200301000-00010

Gleicher, Y., Mosko, J. D., \& McGhee, I. (2017). Improving cardiac operating room to intensive care unit handover using a standardised handover process. BMJ open quality, 6(2), 1-7. https://doi.org/10.1136/bmjoq-2017-000076

Health Resources and Services Administration. (2011). Quality improvement. United States Department of Health and Human Services. https://www.hrsa.gov/sites/default/files/quality/toolbox/pdfs/qualityimprovement.pdf

International Business Model. (2020). IBM SPSS software. https://www.ibm.com/analytics/spss-statistics-software

Joint Commission. (2017). Inadequate hand-off communication. Sentinel Event Alert, 58, 1-6. https://www.jointcommission.org/-/media/tjc/documents/resources/patient-safetytopics/sentinel-event/sea_58_hand_off_comms_9_6_17_final_(1).pdf

Kloda, L. A., Boruff, J. T., \& Soares Cavalcante, A. (2020). A comparison of patient, 
intervention, comparison, outcome (PICO) to a new, alternative clinical question framework for search skills, search results, and self-efficacy: A randomized controlled trial. Journal of the Medical Library Association, 108(2), 185-194.

https://doi-org.www.libproxy.wvu.edu/10.5195/jmla.2020.73

Krimminger, D., Sona, C., Thomas-Horton, E., \& Schallom, M. (2018). A multidisciplinary QI initiative to improve OR-ICU handovers. The American Journal of Nursing, 118(2), 4859. https://doi.org/10.1097/01.NAJ.0000530248.45711.60

Lane-Fall, M. B., Pascual, J. L., Peifer, H. G., Di Taranti, L. J., Collard, M. L., Jablonski, J., Gutsche, J. T., Halpern, S. D., Barg, F. K., Fleisher, L. A., Allen, K., Barry, M., Buddai, S., Chavez, T., Choudhary, M., George, D., Linehan, M., Hernandez, E. T., \& Watts, J.). (2020). A partially structured postoperative handoff protocol improves communication in 2 mixed surgical intensive care units: Findings from the handoffs and transitions in critical care (HATRICC) prospective cohort study. Annals of Surgery, 271(3), 484-493. https://doi.org/10.1097/SLA.0000000000003137

Lavrakas, P. J. (2008). Encyclopedia of survey research methods. SAGE Publications. http://dx.doi.org.wvu.idm.oclc.org/10.4135/9781412963947

Leotsakos, A., Zheng, H., Croteau, R., Loeb, J. M., Sherman, H., Hoffman, C., Morganstein, L., O'Leary, D., Bruneau, C., Lee, P., Duguid, M., Thomeczek, C., van der Schrieck-De Loos, E., \& Munier, B. (2014). Standardization in patient safety: The WHO High 5s project. International Journal for Quality in Health Care 26(2), 109-116. https://doi.org/10.1093/intqhe/mzu010

Marshall, A. P., Tobiano, G., Murphy, N., Comadira, G., Willis, N., Gardiner, T., Hervey, L., Simpson, W., \& Gillespie, B. M. (2019). Handover from operating theatre to the 
intensive care unit: A quality improvement study. Australian Critical Care: Official Journal of the Confederation of Australian Critical Care Nurses, 32(3), 229-236. https://doi.org/10.1016/j.aucc.2018.03.009

Melnyk, B. M., \& Fineout-Overholt, E. (2019). Evidence-based practice in nursing and healthcare: A guide to best practice ( $4^{\text {th }}$ ed.). Wolters Kluwer

Mind Tools. (2019). SWOT analysis: How to develop a strategy for success. https://www.mindtools.com/pages/article/newTMC 05.htm

Nagpal, K., Arora, S., Abboudi, M., Vats, A., Wong, H. W., Manchanda, C., Vincent, C., \& Moorthy, K. (2010). Postoperative handover: Problems, pitfalls, and prevention of error. Annals of Surgery, 252(1), 171-6. https://doi.org/10.1097/SLA.0b013e3181dc3656

Petrovic, M. A., Aboumatar, H., Baumgartner, W. A., Ulatowski, J. A., Moyer, J., Chang, T. Y., Camp, M. S., Kowalski, J., Senger, C. M., \& Martinez, E. A. (2012). Pilot implementation of a perioperative protocol to guide operating room-to-intensive care unit patient handoffs. Journal of Cardiothoracic and Vascular Anesthesia, 26(1), 11-16. https://doi.org/10.1053/j.jvca.2011.07.009

Qualtrics. (2020). Work different. https://www.qualtrics.com/

Safdar, N., Abbo, L. M., Knobloch, M. J., \& Seo, S. K. (2016). Research methods in healthcare Epidemiology: Survey and qualitative research, 37(11), 1272-1277. https://doi.org/10.1017/ice.2016.171

Segall, N., Bonifacio, A. S., Schroeder, R. A., Barbeito, A., Rogers, D., Thornlow, D. K., Emery, J., Kellum, S., Wright, M. C., \& Mark, J. B. (2012). Can we make postoperative patient handovers safer? A systematic review of the literature. Anesthesia and Analgesia, 115(1), 102-15. https://doi.org/10.1213/ANE.0b013e318253af4b 
Talley, D. A., Dunlap, E., Silverman, D., Katzer, S., Huffines, M., Dove, C., Anders, M., Galvagno, S. M., \& Tisherman, S. A. (2019). Improving postoperative handoff in a surgical intensive care unit. Critical CareNnurse, 39(5), e13-e21. https://doi.org/10.4037 /ccn2019523

United States Preventive Services Task Force. (2020). USPSTF recommendations development process: A graphic overview. https://uspreventiveservicestaskforce.org/uspstf/uspstf-recommendations-developmentprocess-graphic-overview

Van Der Walt, J. J. N., Scholl, A. T., Joubert, I. A., \& Petrovic, M. A. (2016). Implementation of a postoperative handoff protocol. Southern African Journal of Anaesthesia and Analgesia, 22(6), 33-37. https://doi.org/10.1080/22201181.2016.1244317

West Virginia University Health System. (2020). Surgical Intensive Care Unit (SICU). WVU Medicine. https://wvumedicine.org/criticalcare/surgical-intensive-care-unit-sicu/

West Virginia University Medicine. (2020). Mission and vision. https://wvumedicine.org/about/leadership-and-more/mission-and-vision/

Wheeler, D. S., Sheets, A. M., \& Ryckman, F. C. (2018). Improving transitions of care between the operating room and intensive care unit. Translational Pediatrics, 7(4), 299-307. https://doi.org/10.21037/tp.2018.09.09

Zaman, Q. N., \& Ali, Z. (2018). Effective handover: A tool for patient's safety. Journal of Postgraduate Medical Institute, 32(3), 233-235. https://www.thefreelibrary.com/EFFECTIVE+HANDOVER $\% 3 \mathrm{a}+\mathrm{A}+\mathrm{TOOL}+\mathrm{FOR}+\mathrm{PATI}$ \%20ENT\%27S+SAFETY.-a0557432484 


\section{Appendix A}

Table 1

Literature Review Synthesis Table

\begin{tabular}{|c|c|c|c|c|c|c|}
\hline $\begin{array}{l}\text { Author and } \\
\text { date }\end{array}$ & $\begin{array}{l}\text { Purpose \& } \\
\text { Variables }\end{array}$ & Design/Method & Sample/Setting & Data Analysis & Findings & $\begin{array}{l}\text { Worth to Practice } \\
\text { LOE } \\
\text { Strengths/Weaknesse } \\
\text { s } \\
\text { Feasibility } \\
\text { Conclusion } \\
\text { Recommendations }\end{array}$ \\
\hline $\begin{array}{l}\text { Krimminger et } \\
\text { al. }(2018)\end{array}$ & $\begin{array}{l}\text { - QI to examine } \\
\text { impact of SHP } \\
\text { between OR to } \\
\text { ICU on } \\
\text { providers' } \\
\text { satisfaction } \\
\text { - Pre/post survey } \\
\text { questions: } \\
\text { - Q1: Satisfied } \\
\text { with OR to ICU } \\
\text { handover } \\
\text { - Q2: Surgery } \\
\text { report was } \\
\text { satisfactory } \\
\text { - Q3: Anesthesia } \\
\text { report was } \\
\text { satisfactory }\end{array}$ & $\begin{array}{l}\text { - Pre/post } \\
\text { observational } \\
\text { QI study } \\
\text { - SHP designed } \\
\text { after literature } \\
\text { review and } \\
\text { input from } \\
\text { surgery, } \\
\text { anesthesia, and } \\
\text { ICU RNs } \\
\text { - One-month } \\
\text { spent educating } \\
\text { handover teams } \\
\text { (surgery, } \\
\text { anesthesia, RT, } \\
\text { ICU staff) } \\
\text { - New SHP } \\
\text { laminated and }\end{array}$ & $\begin{array}{l}\text { - } \mathrm{N}=38 \text { pre and } \\
\text { post-SHP } \\
\text { handovers } \\
\text { - } \mathrm{N}=231 \text { pre- } \\
\text { SHP surveys } \\
\text { - N=95 post- } \\
\text { SHP surveys } \\
\text { (breakdown in } \\
\text { article) } \\
\text { - Adult pts from } \\
\text { OR to CTICU } \\
\text { of a large } \\
\text { university- } \\
\text { affiliated } \\
\text { medical center } \\
\text { - Patient } \\
\text { demographics } \\
\text { not included }\end{array}$ & $\begin{array}{l}\text { - IBM SPSS used } \\
\text { - Kruskal-Wallis } \\
\text { test used to } \\
\text { compare } \\
\text { pre/post survey } \\
\text { results } \\
\text { Statistical } \\
\text { significance was } \\
\text { set at } p=0.05\end{array}$ & 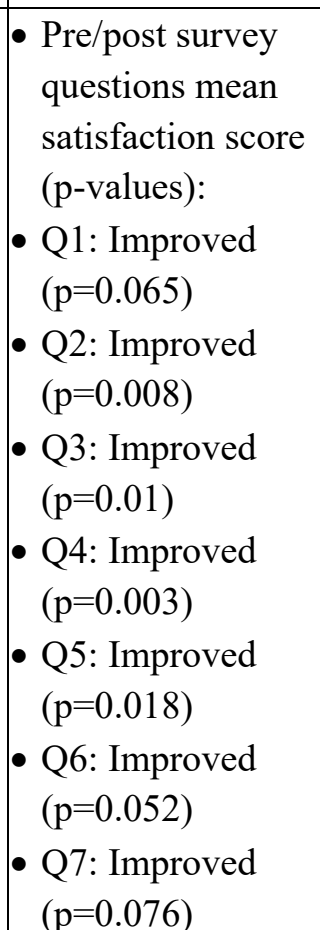 & $\begin{array}{l}\text { - Worth to Practice: } \\
\text { High worth in any } \\
\text { post-op ICU with no } \\
\text { SHP } \\
\text { - LOE: USPSTF } \\
\text { Grade B and } \\
\text { Moderate Strength } \\
\text { of Evidence } \\
\text { - Strengths: Example } \\
\text { SHP included. In- } \\
\text { depth literature } \\
\text { review prior to } \\
\text { implementation. } \\
\text { Well-designed study } \\
\text { with detailed data } \\
\text { collection prior to } \\
\text { and after } \\
\text { implementation. }\end{array}$ \\
\hline
\end{tabular}




\begin{tabular}{|c|c|c|c|c|c|c|}
\hline $\begin{array}{l}\text { Author and } \\
\text { date }\end{array}$ & $\begin{array}{l}\text { Purpose \& } \\
\text { Variables }\end{array}$ & Design/Method & Sample/Setting & Data Analysis & Findings & $\begin{array}{l}\text { Worth to Practice } \\
\text { LOE } \\
\text { Strengths/Weaknesse } \\
\text { s } \\
\text { Feasibility } \\
\text { Conclusion } \\
\text { Recommendations }\end{array}$ \\
\hline & $\begin{array}{l}\text { - Q4: Could hear } \\
\text { all the report } \\
\text { - Q5: Pre-op } \\
\text { anesthesia } \\
\text { assessment } \\
\text { information was } \\
\text { helpful } \\
\text { - Q6: THOR } \\
\text { provided useful } \\
\text { information } \\
\text { - Q7: Received } \\
\text { information } \\
\text { about potential } \\
\text { problems } \\
\text { - Q8: } \\
\text { Interruptions } \\
\text { impaired } \\
\text { handover } \\
\text { process } \\
\text { - Q9: Start and } \\
\text { end of handover } \\
\text { were clear }\end{array}$ & $\begin{array}{l}\text { placed at ICU } \\
\text { bedside; small } \\
\text { laminated card } \\
\text { given to } \\
\text { surgery and } \\
\text { anesthesia to } \\
\text { keep } \\
\text { - 2-year study } \\
\text { - Pre/post survey } \\
\text { 5-point Likert } \\
\text { scale with } \\
\text { 1=strongly } \\
\text { disagree and } \\
\text { 5=strongly } \\
\text { agree } \\
\text { - Each member } \\
\text { of handover } \\
\text { team provided } \\
\text { satisfaction } \\
\text { survey after } \\
\text { handover. } \\
\text { - Anonymity } \\
\text { maintained. }\end{array}$ & & & $\begin{array}{l}\text { Q8: Improved } \\
(\mathrm{p}=0.017) \\
\text { - } 99 \text { : Improved } \\
(\mathrm{p}<0.001) \\
\text { Q10: Improved } \\
(\mathrm{p}=0.008) \\
\text { - } 11: \text { Improved } \\
(\mathrm{p}=0.002) \\
\text { - } \mathrm{Q} 12: \text { Improved } \\
(\mathrm{p}=0.697)\end{array}$ & $\begin{array}{l}\text { Survey results } \\
\text { included anesthesia, } \\
\text { RNs, and surgery. } \\
\text { Conflicts of interest, } \\
\text { limitations, and } \\
\text { affiliations were all } \\
\text { mentioned } \\
\text { - Weaknesses: } \\
\text { Decreased post- } \\
\text { intervention surveys. } \\
\text { Specific patient } \\
\text { characteristics, i.e. } \\
\text { severity of patient } \\
\text { status post-op was } \\
\text { not included. } \\
\text { Blinding and } \\
\text { selection bias } \\
\text { concerns due to the } \\
\text { nature of the study } \\
\text { (surveys and pre- } \\
\text { implementation } \\
\text { education alert } \\
\text { participants of } \\
\text { design). Survey }\end{array}$ \\
\hline
\end{tabular}




\begin{tabular}{|c|c|c|c|c|c|c|}
\hline $\begin{array}{l}\text { Author and } \\
\text { date }\end{array}$ & $\begin{array}{l}\text { Purpose \& } \\
\text { Variables }\end{array}$ & Design/Method & Sample/Setting & Data Analysis & Findings & $\begin{array}{l}\text { Worth to Practice } \\
\text { LOE } \\
\text { Strengths/Weaknesse } \\
\text { s } \\
\text { Feasibility } \\
\text { Conclusion } \\
\text { Recommendations }\end{array}$ \\
\hline & $\begin{array}{l}\text { - Q10: Person } \\
\text { handing off } \\
\text { patient was } \\
\text { under time } \\
\text { pressure } \\
\text { - Q11: Person } \\
\text { taking on } \\
\text { responsibility } \\
\text { for patient was } \\
\text { under time } \\
\text { pressure } \\
\text { Q12: Technical } \\
\text { errors were } \\
\text { encountered } \\
\text { during handover }\end{array}$ & $\begin{array}{l}\text { - Non-CTICU re- } \\
\text { searcher } \\
\text { retrieved the } \\
\text { surveys weekly } \\
\text { - SHP flow: } \\
\text { provider } \\
\text { introductions, } \\
\text { equipment } \\
\text { handoff, } \\
\text { surgery then } \\
\text { anesthesia } \\
\text { report, all } \\
\text { parties' } \\
\text { questions } \\
\text { answered, } \\
\text { report } \\
\text { concluded. No } \\
\text { interruptions } \\
\text { during report }\end{array}$ & & & & $\begin{array}{l}\text { results did not state } \\
\text { which Likert-scale } \\
\text { answers statistics } \\
\text { were based on } \\
\text { - Feasibility: This } \\
\text { study is greatly } \\
\text { feasible for basically } \\
\text { any ICU, especially } \\
\text { those lacking a SHP. } \\
\text { It comes at little cost } \\
\text { financially for an } \\
\text { institution and } \\
\text { education prior to } \\
\text { implementation } \\
\text { would not require a } \\
\text { great number of } \\
\text { resources or time. } \\
\text { - Conclusion: This } \\
\text { study shows } \\
\text { statistically } \\
\text { significant } \\
\text { improvements in } \\
\text { providers' } \\
\text { satisfaction with }\end{array}$ \\
\hline
\end{tabular}




\begin{tabular}{|c|c|c|c|c|c|c|}
\hline $\begin{array}{l}\text { Author and } \\
\text { date }\end{array}$ & $\begin{array}{l}\text { Purpose \& } \\
\text { Variables }\end{array}$ & Design/Method & Sample/Setting & Data Analysis & Findings & $\begin{array}{l}\text { Worth to Practice } \\
\text { LOE } \\
\text { Strengths/Weaknesse } \\
\text { s } \\
\text { Feasibility } \\
\text { Conclusion } \\
\text { Recommendations }\end{array}$ \\
\hline & & & & & & $\begin{array}{l}\text { numerous handover } \\
\text { areas after SHP } \\
\text { implementation. } \\
\text { Overall, this was a } \\
\text { well-conducted and } \\
\text { readable study and } \\
\text { could be similarly } \\
\text { conducted in most } \\
\text { ICUs. } \\
\text { - Recommendations: } \\
\text { Improved strategies } \\
\text { need to be } \\
\text { considered for } \\
\text { increasing survey } \\
\text { participation. } \\
\text { Perhaps an RCT-like } \\
\text { study could be } \\
\text { constructed to } \\
\text { simultaneously } \\
\text { assess and compare } \\
\text { satisfaction with the } \\
\text { handover process } \\
\text { between teams using } \\
\text { an SHP and teams }\end{array}$ \\
\hline
\end{tabular}




\begin{tabular}{|c|c|c|c|c|c|c|}
\hline $\begin{array}{l}\text { Author and } \\
\text { date }\end{array}$ & $\begin{array}{l}\text { Purpose \& } \\
\text { Variables }\end{array}$ & Design/Method & Sample/Setting & Data Analysis & Findings & $\begin{array}{l}\text { Worth to Practice } \\
\text { LOE } \\
\text { Strengths/Weaknesse } \\
\text { s } \\
\text { Feasibility } \\
\text { Conclusion } \\
\text { Recommendations }\end{array}$ \\
\hline & & & & & & $\begin{array}{l}\text { not using one. This } \\
\text { way satisfaction } \\
\text { could be compared } \\
\text { over the exact same } \\
\text { time period. }\end{array}$ \\
\hline $\begin{array}{l}\text { Talley et al., } \\
\text { (2019). }\end{array}$ & $\begin{array}{l}\text { - Assess post-op } \\
\text { ICU nurse } \\
\text { satisfaction after } \\
\text { implementation } \\
\text { of SHP } \\
\text { - Survey } \\
\text { questions: } \\
\text { - Q1: Received } \\
\text { handoff from } \\
\text { anesthesia upon } \\
\text { patient's return } \\
\text { from operating } \\
\text { room } \\
\text { - Q2: Satisfied } \\
\text { with handoff } \\
\text { from anesthesia } \\
\text { - Q3: Perceived } \\
\text { handoff from }\end{array}$ & $\begin{array}{l}\text { - QI } \\
\text { Observational } \\
\text { pre/post study } \\
\text { - SHP designed } \\
\text { and evolved } \\
\text { after initial } \\
\text { pilot with SICU } \\
\text { nurses. APRNs, } \\
\text { surgery, and } \\
\text { anesthesia } \\
\text { contributed } \\
\text { subsequently } \\
\text { - Education } \\
\text { provided via } \\
\text { staff meetings, } \\
\text { emails, daily } \\
\text { huddles, direct } \\
\text { communication, }\end{array}$ & $\begin{array}{l}\text { - N=69 nurses } \\
\text { surveyed pre- } \\
\text { SHP handovers } \\
\text { - N=68 nurses } \\
\text { surveyed post- } \\
\text { SHP handovers } \\
\text { - Number of } \\
\text { handovers not } \\
\text { included } \\
\text { - University of } \\
\text { Maryland } \\
\text { Medical Center } \\
\text { 757-bed } \\
\text { tertiary care } \\
\text { facility, 24-bed } \\
\text { adult SICU } \\
\text { - Mean age of } \\
\text { department's }\end{array}$ & $\begin{array}{l}\text { - Microsoft Excel } \\
\text { for Windows } \\
\text { used } \\
\text { - Eleven items } \\
\text { used different } \\
\text { variations of } \\
\text { Likert scales } \\
\text { - } 2 \text { items were } \\
\text { answered as } \\
\text { yes/no. } \\
\text { - Data evaluated } \\
\text { using } \chi 2 \text { test for } \\
\text { unpaired data. } \\
\text { - Analysis not } \\
\text { completed on } \\
\text { paired data }\end{array}$ & 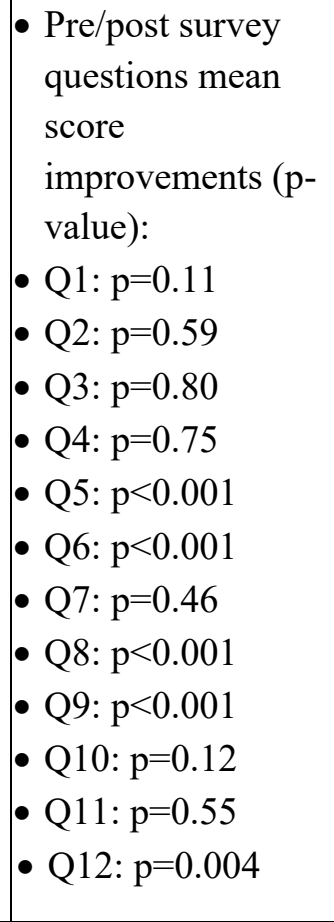 & $\begin{array}{l}\text { - Worth to Practice: } \\
\text { High value of worth } \\
\text { in any post-op ICU } \\
\text { lacking a current } \\
\text { SHP } \\
\text { - LOE: USPSTF } \\
\text { Grade B and } \\
\text { Moderate Strength } \\
\text { of Evidence } \\
\text { - Strengths: Example } \\
\text { SHP included. } \\
\text { Strong mention of } \\
\text { background problem } \\
\text { based on literature } \\
\text { review prior. The } \\
\text { study piloted a few } \\
\text { checklists prior to } \\
\text { implementation and }\end{array}$ \\
\hline
\end{tabular}




\begin{tabular}{|c|c|c|c|c|c|c|}
\hline $\begin{array}{l}\text { Author and } \\
\text { date }\end{array}$ & $\begin{array}{l}\text { Purpose \& } \\
\text { Variables }\end{array}$ & Design/Method & Sample/Setting & Data Analysis & Findings & $\begin{array}{l}\text { Worth to Practice } \\
\text { LOE } \\
\text { Strengths/Weaknesse } \\
\text { s } \\
\text { Feasibility } \\
\text { Conclusion } \\
\text { Recommendations }\end{array}$ \\
\hline & $\begin{array}{l}\text { anesthesia as } \\
\text { important } \\
\text { - Q4: Can identify } \\
\text { anesthesia } \\
\text { providers } \\
\text { - Q5: Received } \\
\text { handoff from } \\
\text { surgery upon } \\
\text { patient's return } \\
\text { from operating } \\
\text { room } \\
\text { - Q6: Satisfied } \\
\text { with handoff } \\
\text { from surgery } \\
\text { - Q7: Perceived } \\
\text { handoff from } \\
\text { surgery as } \\
\text { important } \\
\text { - Q8: Can identify } \\
\text { surgery } \\
\text { providers }\end{array}$ & $\begin{array}{l}\text { and grand } \\
\text { round } \\
\text { presentation } \\
\text { - Signs created } \\
\text { mapping out } \\
\text { SHP and placed } \\
\text { at ICU bedside } \\
\text { - } 2 \text { survey } \\
\text { administrators } \\
\text { collected } \\
\text { confidential } \\
\text { surveys } \\
\text { - Length of study } \\
\text { not included } \\
\text { - SHP steps } \\
\text { involved ICU } \\
\text { physician, } \\
\text { surgeon, RN, } \\
\text { and anesthesia } \\
\text { at bedside, RN } \\
\text { initiates report } \\
\text { is to begin, } \\
\text { surgery }\end{array}$ & $\begin{array}{l}\text { patients is } 58 \\
\text { years old, } 58 \% \\
\text { male and } 42 \% \\
\text { female, and } \\
>50 \% \text { have a } \\
\text { chronic health } \\
\text { condition }\end{array}$ & & - $\mathrm{Q} 13: \mathrm{p}=0.002$ & $\begin{array}{l}\text { incorporated a } \\
\text { wealth of feedback } \\
\text { from a very diverse } \\
\text { group of clinicians. } \\
\text { Study limitations } \\
\text { were included } \\
\text { - Weaknesses: Study } \\
\text { did not survey other } \\
\text { clinicians in the } \\
\text { handover besides } \\
\text { RNs. Specific } \\
\text { patient } \\
\text { characteristics, i.e. } \\
\text { severity of patient } \\
\text { status post-op was } \\
\text { not included. } \\
\text { Blinding and } \\
\text { selection bias } \\
\text { concerns due to the } \\
\text { nature of the study } \\
\text { (surveys and pre- } \\
\text { implementation } \\
\text { education alert } \\
\text { participants of }\end{array}$ \\
\hline
\end{tabular}




\begin{tabular}{|c|c|c|c|c|c|c|}
\hline $\begin{array}{l}\text { Author and } \\
\text { date }\end{array}$ & $\begin{array}{l}\text { Purpose \& } \\
\text { Variables }\end{array}$ & Design/Method & Sample/Setting & Data Analysis & Findings & $\begin{array}{l}\text { Worth to Practice } \\
\text { LOE } \\
\text { Strengths/Weaknesse } \\
\text { s } \\
\text { Feasibility } \\
\text { Conclusion } \\
\text { Recommendations }\end{array}$ \\
\hline & $\begin{array}{l}\text { - Q9: Frequently } \\
\text { feeling included } \\
\text { in the handoff } \\
\text { - Q10: Frequently } \\
\text { feeling like all } \\
\text { questions were } \\
\text { answered } \\
\text { - Q11: Feeling } \\
\text { comfortable } \\
\text { speaking up } \\
\text { Q12: Frequently } \\
\text { feeling too busy } \\
\text { with routine } \\
\text { activities to stop } \\
\text { and participate } \\
\text { in handoff } \\
\text { Q13: Frequently } \\
\text { feeling too busy } \\
\text { with urgent } \\
\text { activities to stop } \\
\text { and participate } \\
\text { in handoff }\end{array}$ & $\begin{array}{l}\text { conducts report, } \\
\text { anesthesia gives } \\
\text { report, } \\
\text { questions are } \\
\text { answered, and } \\
\text { report ends }\end{array}$ & & & & $\begin{array}{l}\text { design). Specific } \\
\text { results pertaining to } \\
\text { Likert categories } \\
\text { were not included. } \\
\text { - Feasibility: This } \\
\text { study is also feasible } \\
\text { for any ICU with a } \\
\text { poor or non-existent } \\
\text { SHP. Project } \\
\text { implementation is } \\
\text { cheap for an } \\
\text { institution and } \\
\text { education prior to } \\
\text { implementation is } \\
\text { flexible } \\
\text { - Conclusion: This } \\
\text { study shows } \\
\text { statistically } \\
\text { significant } \\
\text { improvements in RN } \\
\text { satisfaction with } \\
\text { handovers after SHP } \\
\text { implementation. } \\
\text { Particularly, }\end{array}$ \\
\hline
\end{tabular}




\begin{tabular}{|c|c|c|c|c|c|c|}
\hline $\begin{array}{l}\text { Author and } \\
\text { date }\end{array}$ & $\begin{array}{l}\text { Purpose \& } \\
\text { Variables }\end{array}$ & Design/Method & Sample/Setting & Data Analysis & Findings & $\begin{array}{l}\text { Worth to Practice } \\
\text { LOE } \\
\text { Strengths/Weaknesse } \\
\text { s } \\
\text { Feasibility } \\
\text { Conclusion } \\
\text { Recommendations }\end{array}$ \\
\hline & & & & & & $\begin{array}{l}\text { improved surgeon } \\
\text { report satisfaction } \\
\text { and an overall } \\
\text { feeling of } \\
\text { importance and lack } \\
\text { of stress during the } \\
\text { handover was } \\
\text { reported. This study } \\
\text { could be easily } \\
\text { repeated, and more } \\
\text { studies could be } \\
\text { conducted to assess } \\
\text { other survey } \\
\text { satisfaction } \\
\text { categories } \\
\text { - Recommendations: } \\
\text { More studies with } \\
\text { surveys assessing } \\
\text { surgeons and } \\
\text { anesthesia providers } \\
\text { need to be } \\
\text { conducted. Studies } \\
\text { should also do } \\
\text { follow-up studies a }\end{array}$ \\
\hline
\end{tabular}




\begin{tabular}{|c|c|c|c|c|c|c|}
\hline $\begin{array}{l}\text { Author and } \\
\text { date }\end{array}$ & $\begin{array}{l}\text { Purpose \& } \\
\text { Variables }\end{array}$ & Design/Method & Sample/Setting & Data Analysis & Findings & $\begin{array}{l}\text { Worth to Practice } \\
\text { LOE } \\
\text { Strengths/Weaknesse } \\
\text { s } \\
\text { Feasibility } \\
\text { Conclusion } \\
\text { Recommendations }\end{array}$ \\
\hline & & & & & & $\begin{array}{l}\text { year or two after } \\
\text { initial } \\
\text { implementation } \\
\text { studies to assess if } \\
\text { SHPs are still being } \\
\text { utilized. }\end{array}$ \\
\hline $\begin{array}{l}\text { Petrovic et al., } \\
(2012)\end{array}$ & $\begin{array}{l}\text { - To assess if } \\
\text { implementation } \\
\text { of a SHP from } \\
\text { OR to ICU } \\
\text { would improve } \\
\text { provider } \\
\text { satisfaction } \\
\text { - Pre/post survey } \\
\text { questions: } \\
\text { - Q1: I was } \\
\text { satisfied with } \\
\text { the } \\
\text { - OR to ICU } \\
\text { handoff } \\
\text { - Q2: Surgery } \\
\text { provider report } \\
\text { satisfactory }\end{array}$ & $\begin{array}{l}\text { - Prospective, } \\
\text { unblinded } \\
\text { pre/post } \\
\text { observational } \\
\text { study } \\
\text { - SHP designed } \\
\text { after input from } \\
\text { focus groups } \\
\text { representing } \\
\text { ICU nurses, } \\
\text { anesthesia, } \\
\text { intensivists, } \\
\text { NPs, PAs, } \\
\text { surgeons } \\
\text { - All clinicians } \\
\text { normally } \\
\text { involved in }\end{array}$ & $\begin{array}{l}\text { - } \mathrm{N}=30 \text { pre- } \\
\text { implementation } \\
\text { handovers } \\
\text { - } \mathrm{N}=30 \text { post- } \\
\text { implementation } \\
\text { handovers } \\
\text { - } \mathrm{N}=29 \text { pre and } \\
25 \text { post-SHP } \\
\text { surgery } \\
\text { clinician } \\
\text { surveys } \\
\text { - } \mathrm{N}=65 \text { pre- and } \\
44 \text { post-SHP } \\
\text { anesthesia } \\
\text { surveys } \\
\text { - } \mathrm{N}=53 \text { pre- and } \\
36 \text { post-SHP }\end{array}$ & $\begin{array}{l}\text { - Provider } \\
\text { satisfaction } \\
\text { based on a 5- } \\
\text { point Likert } \\
\text { scale (strongly } \\
\text { disagree, } \\
\text { disagree, } \\
\text { neutral, agree, } \\
\text { and strongly } \\
\text { agree). } \\
\text { - Responses } \\
\text { analyzed and a } \\
\text { Cronbach alpha } \\
\text { coefficient was } \\
\text { calculated. } \\
\text { - p Value } \\
\text { calculated using }\end{array}$ & $\begin{array}{l}\text { - Pre/post survey } \\
\text { questions mean } \\
\text { score } \\
\text { improvements with } \\
\text { percentages based } \\
\text { on "strongly } \\
\text { agree" answer per } \\
\text { group (p-value): } \\
\text { - Q1: ICU nurses } \\
33 \% \text { to 50\% } \\
\text { (p=0.269); ICU } \\
\text { intensivist } 81 \% \text { to } \\
83 \% \text { (p=1); } \\
\text { Anesthesia/surgery } \\
53 \% \text { to } 78 \% \\
\text { (p=0.001) }\end{array}$ & \begin{tabular}{|l} 
- Worth to Practice: \\
Also valuable to real \\
practice due to risks \\
of \\
miscommunication \\
in ICUs with no SHP \\
- LOE: USPSTF \\
Grade B and \\
Moderate Strength \\
of Evidence \\
- Strengths: All \\
disciplines involved \\
in the handover were \\
surveyed. Data \\
collection and \\
statistical analysis \\
thorough and
\end{tabular} \\
\hline
\end{tabular}




\begin{tabular}{|c|c|c|c|c|c|c|}
\hline $\begin{array}{l}\text { Author and } \\
\text { date }\end{array}$ & $\begin{array}{l}\text { Purpose \& } \\
\text { Variables }\end{array}$ & Design/Method & Sample/Setting & Data Analysis & Findings & $\begin{array}{l}\text { Worth to Practice } \\
\text { LOE } \\
\text { Strengths/Weaknesse } \\
\text { s } \\
\text { Feasibility } \\
\text { Conclusion } \\
\text { Recommendations }\end{array}$ \\
\hline & $\begin{array}{l}\text { - Q3: Anesthesia } \\
\text { provider report } \\
\text { satisfactory } \\
\text { - Q4: I could hear } \\
\text { all the report } \\
\text { - Q5: I received } \\
\text { info about } \\
\text { potential } \\
\text { problems } \\
\text { - Q6: I received } \\
\text { information on } \\
\text { follow-up } \\
\text { - Q7: Physical } \\
\text { transfers went } \\
\text { smoothly } \\
\text { - Q8: Hand off } \\
\text { start and end } \\
\text { clear } \\
\text { - Q9: I received } \\
\text { anticipatory } \\
\text { guidance }\end{array}$ & $\begin{array}{l}\text { handover } \\
\text { process were } \\
\text { emailed new } \\
\text { SHP and } \\
\text { provided visual } \\
\text { aid } \\
\text { - } 2.5 \text { months } \\
\text { educational } \\
\text { training before } \\
\text { implementation } \\
\text { of new SHP } \\
\text { - Laminated } \\
\text { SHPs posted } \\
\text { above each ICU } \\
\text { bed and pocket } \\
\text { cards also } \\
\text { administered } \\
\text { - Handover } \\
\text { process guided } \\
\text { by CSICU } \\
\text { champions and } \\
\text { - Handover } \\
\text { observers not }\end{array}$ & $\begin{array}{l}\text { ICU intensivist } \\
\text { surveys } \\
\text { - } \mathrm{N}=22 \text { pre- and } \\
32 \text { post-SHP } \\
\text { surveys } \\
\text { - } \mathrm{N}=170 \text { total } \\
\text { pre-SHP } \\
\text { surveys } \\
\text { - } \mathrm{N}=138 \text { post- } \\
\text { SHP surveys } \\
\text { 15-bed adult } \\
\text { CSICU in a } \\
\text { large tertiary } \\
\text { hospital } \\
\text { - Patient } \\
\text { demographics } \\
\text { not included }\end{array}$ & $\begin{array}{l}\text { the Fisher exact, } \\
\text { 2-tailed test. }\end{array}$ & $\begin{array}{l}\text { - Q2: ICU nurses } \\
45 \% \text { to } 59 \% \\
\text { ( } p=0.407 \text { ); ICU } \\
\text { intensivist } 75 \% \text { to } \\
86 \% \text { ( } p=0.393 \text { ) } \\
\text { - Q3: ICU nurses } \\
41 \% \text { to } 59 \% \\
\text { ( } p=0.268 \text { ); ICU } \\
\text { intensivist } 77 \% \text { to } \\
\text { 93\% ( }=0.071 \text { ) } \\
\text { Q4: ICU nurses } \\
\text { 18\% to 50\% } \\
\text { ( } p=0.023 \text { ); ICU } \\
\text { intensivist } 68 \% \text { to } \\
78 \% \text { ( }=0.438 \text { ); } \\
\text { Anesthesia/surgery } \\
53 \% \text { to } 74 \% \\
\text { ( } p=0.008 \text { ) } \\
\text { Q5: ICU nurses } \\
33 \% \text { to } 47 \% \\
\text { ( } p=0.4 \text { ); ICU } \\
\text { intensivist } 60 \% \text { to } \\
79 \% \text { ( }=0.092 \text { ) }\end{array}$ & $\begin{array}{l}\text { presented } \\
\text { aesthetically. } \\
\text { - Weaknesses: Did } \\
\text { not include example } \\
\text { of SHP in journal. } \\
\text { Specific patient } \\
\text { characteristics, i.e. } \\
\text { severity of patient } \\
\text { status post-op was } \\
\text { not included. } \\
\text { Blinding and } \\
\text { selection bias } \\
\text { concerns due to the } \\
\text { nature of the study } \\
\text { (surveys and pre- } \\
\text { implementation } \\
\text { education alert } \\
\text { participants of } \\
\text { design). Conflicts of } \\
\text { interest and } \\
\text { affiliations not } \\
\text { included. } \\
\text { - Feasibility: This is } \\
\text { another feasible }\end{array}$ \\
\hline
\end{tabular}




\begin{tabular}{|c|c|c|c|c|c|c|}
\hline $\begin{array}{l}\text { Author and } \\
\text { date }\end{array}$ & $\begin{array}{l}\text { Purpose \& } \\
\text { Variables }\end{array}$ & Design/Method & Sample/Setting & Data Analysis & Findings & $\begin{array}{l}\text { Worth to Practice } \\
\text { LOE } \\
\text { Strengths/Weaknesse } \\
\text { s } \\
\text { Feasibility } \\
\text { Conclusion } \\
\text { Recommendations }\end{array}$ \\
\hline & & $\begin{array}{l}\text { part of } \\
\text { handover team } \\
\text { and did not } \\
\text { participate in } \\
\text { handover } \\
\text { - Anonymity } \\
\text { maintained for } \\
\text { surveys and } \\
\text { participation } \\
\text { voluntary } \\
\text { - 6-month study } \\
\text { - SHP flow: the } \\
\text { transfer of } \\
\text { equipment, the } \\
\text { transfer of } \\
\text { information } \\
\text { (order not } \\
\text { specified), a } \\
\text { period allowed } \\
\text { for questions, } \\
\text { and conclusion } \\
\text { of report. }\end{array}$ & & & 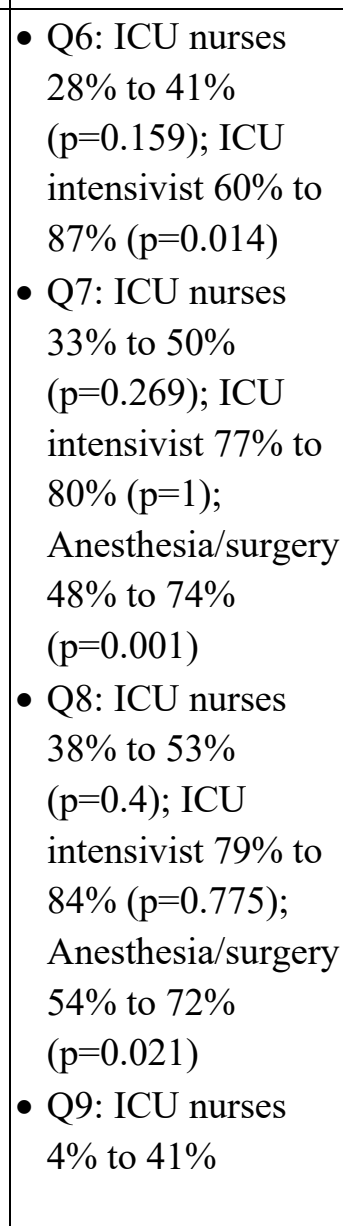 & $\begin{array}{l}\text { study that requires } \\
\text { little financial input } \\
\text { and relatively little } \\
\text { time and resources } \\
\text { for education and } \\
\text { implementation. } \\
\text { - Conclusion: This is } \\
\text { another study that } \\
\text { shows a correlation } \\
\text { between a SHP and } \\
\text { staff satisfaction. It } \\
\text { was especially } \\
\text { interesting to see this } \\
\text { study showed most } \\
\text { improvements in OR } \\
\text { staff satisfaction } \\
\text { compared to RNs. } \\
\text { - Recommendations: } \\
\text { This is another study } \\
\text { showing the benefit } \\
\text { of a structured, } \\
\text { organized, and well- } \\
\text { designed SHP on } \\
\text { improved }\end{array}$ \\
\hline
\end{tabular}




\begin{tabular}{|c|c|c|c|c|c|c|}
\hline $\begin{array}{l}\text { Author and } \\
\text { date }\end{array}$ & $\begin{array}{l}\text { Purpose \& } \\
\text { Variables }\end{array}$ & Design/Method & Sample/Setting & Data Analysis & Findings & $\begin{array}{l}\text { Worth to Practice } \\
\text { LOE } \\
\text { Strengths/Weaknesse } \\
\text { s } \\
\text { Feasibility } \\
\text { Conclusion } \\
\text { Recommendations }\end{array}$ \\
\hline & & $\begin{array}{l}\text { - 5-point Likert } \\
\text { scale }\end{array}$ & & & $\begin{array}{l}(\mathrm{p}=0.004) ; \mathrm{ICU} \\
\text { intensivist } 60 \% \text { to } \\
78 \%(\mathrm{p}=0.14)\end{array}$ & $\begin{array}{l}\text { communication and } \\
\text { overall quality of OR } \\
\text { to ICU handovers. } \\
\text { More studies could } \\
\text { be based off of this } \\
\text { study to assess other } \\
\text { satisfaction } \\
\text { questions. }\end{array}$ \\
\hline $\begin{array}{l}\text { Segall et al., } \\
(2016)\end{array}$ & $\begin{array}{l}\text { - Assess impact } \\
\text { of newly } \\
\text { developed OR } \\
\text { to ICU SHP } \\
\text { Three years } \\
\text { after } \\
\text { implementation } \\
\text { asked } \\
\text { anesthesia, } \\
\text { surgery, OR } \\
\text { nurses, and } \\
\text { SICU nurses to } \\
\text { complete } \\
\text { satisfaction } \\
\text { survey. }\end{array}$ & $\begin{array}{l}\text { - Pre/post-SHP } \\
\text { intervention } \\
\text { observational } \\
\text { study } \\
\text { - Observed pre- } \\
\text { SHP handovers } \\
\text { and collected } \\
\text { data } \\
\text { - Gathered input } \\
\text { from surgery, } \\
\text { anesthesia, RTs, } \\
\text { and SICU } \\
\text { nurses via focus } \\
\text { groups to } \\
\text { develop SHP }\end{array}$ & $\begin{array}{l}\text { - } \mathrm{N}=49 \text { pre-SHP } \\
\text { handover } \\
\text { observations } \\
\text { - } \mathrm{N}=49 \text { post- } \\
\text { SHP } \\
\text { observations } \\
\text { - } \mathrm{N}=56 \text { care } \\
\text { providers } \\
\text { answering } \\
\text { post-SHP } \\
\text { implementation } \\
\text { surveys } \\
\text { - The SICU at } \\
\text { Durham VA }\end{array}$ & $\begin{array}{l}\text { - Student's one- } \\
\text { sample t-test } \\
\text { used to compare } \\
\text { satisfaction } \\
\text { survey scores to } \\
\text { the expected } \\
\text { score of } 3 \\
\text { - Statistically } \\
\text { significant value } \\
\text { set at } p<0.05\end{array}$ & $\begin{array}{l}\text { - Post-SHP } \\
\text { implementation } \\
\text { mean scores with } \\
\text { p-value for only } \\
\text { overall satisfaction } \\
\text { with new SHP: } \\
\text { - Q1: } 1 \text { to } 5 \\
\text { - Q2: } 1 \text { to } 4 \\
\text { - Q3: } 1 \text { to } 5 \\
\text { - Q4: } 1 \text { to } 4 \\
\text { - Q5: } 1 \text { to } 4 \\
\text { - Q6: } 1 \text { to } 4 \\
\text { - Q7: } 1 \text { to } 4(\mathrm{p}< \\
\text { 0.0001) }\end{array}$ & $\begin{array}{l}\text { - Worth to Practice: } \\
\text { Yes. Shows } \\
\text { improved } \\
\text { satisfaction after } \\
\text { SHP } \\
\text { implementation. } \\
\text { - LOE: USPSTF } \\
\text { Grade B and } \\
\text { Moderate Strength } \\
\text { of Evidence } \\
\text { - Strengths: Post- } \\
\text { implementation } \\
\text { surveys were } \\
\text { conducted three } \\
\text { years after }\end{array}$ \\
\hline
\end{tabular}




\begin{tabular}{|c|c|c|c|c|c|c|}
\hline $\begin{array}{l}\text { Author and } \\
\text { date }\end{array}$ & $\begin{array}{l}\text { Purpose \& } \\
\text { Variables }\end{array}$ & Design/Method & Sample/Setting & Data Analysis & Findings & $\begin{array}{l}\text { Worth to Practice } \\
\text { LOE } \\
\text { Strengths/Weaknesse } \\
\text { s } \\
\text { Feasibility } \\
\text { Conclusion } \\
\text { Recommendations }\end{array}$ \\
\hline & $\begin{array}{l}\text { Questions } \\
\text { included: } \\
\text { - Q1: Passing on } \\
\text { all critically } \\
\text { relevant patient } \\
\text { information } \\
\text { - Q2: Passing on } \\
\text { all major } \\
\text { concerns } \\
\text { - Q3: Passing on } \\
\text { the care plan } \\
\text { - Q4: Getting } \\
\text { questions } \\
\text { answered } \\
\text { - Q5: Efficiency } \\
\text { - Q6: } \\
\text { Interruptions } \\
\text { Q7: Overall } \\
\text { satisfaction with } \\
\text { handovers }\end{array}$ & $\begin{array}{l}\text { - Simulations } \\
\text { conducted prior } \\
\text { to } \\
\text { implementation } \\
\text { of new SHP } \\
\text { - Survey was } \\
\text { Likert-like } \\
\text { scale with } 1 \\
\text { being "the } \\
\text { previous } \\
\text { handover was } \\
\text { much better" } \\
\text { and } 5 \text { being } \\
\text { "the current } \\
\text { handover is } \\
\text { much better. }\end{array}$ & $\begin{array}{l}\text { Medical Center } \\
\text { 11-bed unit } \\
\text { - Patient } \\
\text { demographics } \\
\text { not included }\end{array}$ & & & $\begin{array}{l}\text { implementation, and } \\
\text { satisfaction was still } \\
\text { improved. Example } \\
\text { SHP included in } \\
\text { study. Used actual } \\
\text { simulations to } \\
\text { prepare staff for the } \\
\text { handover process. A } \\
\text { lot of good graphs } \\
\text { and charts included. } \\
\text { - Weaknesses: } \\
\text { Survey results did } \\
\text { not differentiate } \\
\text { which providers } \\
\text { completed the } \\
\text { surveys. Survey } \\
\text { results were not } \\
\text { specific enough. } \\
\text { Blinding and } \\
\text { selection bias } \\
\text { concerns due to the } \\
\text { nature of the study } \\
\text { (surveys and pre- } \\
\text { implementation }\end{array}$ \\
\hline
\end{tabular}




\begin{tabular}{|c|c|c|c|c|c|c|}
\hline $\begin{array}{l}\text { Author and } \\
\text { date }\end{array}$ & $\begin{array}{l}\text { Purpose \& } \\
\text { Variables }\end{array}$ & Design/Method & Sample/Setting & Data Analysis & Findings & $\begin{array}{l}\text { Worth to Practice } \\
\text { LOE } \\
\text { Strengths/Weaknesse } \\
\text { s } \\
\text { Feasibility } \\
\text { Conclusion } \\
\text { Recommendations }\end{array}$ \\
\hline & & & & & & $\begin{array}{l}\text { education alert } \\
\text { participants of } \\
\text { design). } \\
\text { - Feasibility: This } \\
\text { study is feasible for } \\
\text { real-world } \\
\text { implementation. One } \\
\text { concern would be } \\
\text { finding time and } \\
\text { resources to conduct } \\
\text { simulations before } \\
\text { implementation. } \\
\text { Although } \\
\text { simulations would } \\
\text { be beneficial, } \\
\text { organizing them } \\
\text { could prove costly } \\
\text { and/or difficult due } \\
\text { to scheduling } \\
\text { concerns } \\
\text { - Conclusion: This } \\
\text { was yet another } \\
\text { study showing } \\
\text { improved }\end{array}$ \\
\hline
\end{tabular}




\begin{tabular}{|c|c|c|c|c|c|c|}
\hline $\begin{array}{l}\text { Author and } \\
\text { date }\end{array}$ & $\begin{array}{l}\text { Purpose \& } \\
\text { Variables }\end{array}$ & Design/Method & Sample/Setting & Data Analysis & Findings & $\begin{array}{l}\text { Worth to Practice } \\
\text { LOE } \\
\text { Strengths/Weaknesse } \\
\text { s } \\
\text { Feasibility } \\
\text { Conclusion } \\
\text { Recommendations }\end{array}$ \\
\hline & & & & & & $\begin{array}{l}\text { satisfaction with } \\
\text { SHPs. The study had } \\
\text { a lot of data, but } \\
\text { overall it did not } \\
\text { include enough } \\
\text { survey result } \\
\text { specifics such as } \\
\text { statistical } \\
\text { comparisons of other } \\
\text { survey results or } \\
\text { breakdown of how } \\
\text { many surveys were } \\
\text { completed by which } \\
\text { type of providers. } \\
\text { - Recommendations: } \\
\text { The study could have } \\
\text { been improved by } \\
\text { first collecting pre- } \\
\text { intervention surveys } \\
\text { in order to compare } \\
\text { results with post- } \\
\text { SHP surveys. Also, } \\
\text { the SHP used for this } \\
\text { study had an SBAR }\end{array}$ \\
\hline
\end{tabular}




\begin{tabular}{|c|c|c|c|c|c|c|}
\hline $\begin{array}{l}\text { Author and } \\
\text { date }\end{array}$ & $\begin{array}{l}\text { Purpose \& } \\
\text { Variables }\end{array}$ & Design/Method & Sample/Setting & Data Analysis & Findings & $\begin{array}{l}\text { Worth to Practice } \\
\text { LOE } \\
\text { Strengths/Weaknesse } \\
\text { s } \\
\text { Feasibility } \\
\text { Conclusion } \\
\text { Recommendations }\end{array}$ \\
\hline & & & & & & $\begin{array}{l}\text { section where } \\
\text { surgery and } \\
\text { anesthesia alternated } \\
\text { frequently. Perhaps } \\
\text { this is more } \\
\text { beneficial compared } \\
\text { to having surgery } \\
\text { and anesthesia only } \\
\text { alternate once, or } \\
\text { maybe it is not } \\
\text { beneficial. A future } \\
\text { study could maybe } \\
\text { compare different } \\
\text { SHPs and assess } \\
\text { survey results to } \\
\text { compare the two. }\end{array}$ \\
\hline $\begin{array}{l}\text { Van Der Walt } \\
\text { et al., (2016) }\end{array}$ & \begin{tabular}{|l} 
- Determine if \\
SHP \\
implementation \\
improves \\
quality of \\
handover team \\
satisfaction
\end{tabular} & $\begin{array}{l}\text { - Observational } \\
\text { pre/post study } \\
\text { - SHP designed } \\
\text { - One-month } \\
\text { educating } \\
\text { handover staff } \\
\text { via }\end{array}$ & $\begin{array}{l}\text { - N=30 pre and } \\
\text { post-SHP } \\
\text { handovers } \\
\text { - SHP modified } \\
\text { from unknown } \\
\text { U.S. protocol }\end{array}$ & $\begin{array}{l}\text { - Stata MP. } \\
\text { (StataCorp LP, } \\
\text { College Station, } \\
\text { TX, USA) used } \\
\text { - Kruskal-Wallis } \\
\text { and Mann-- } \\
\text { Whitney tests }\end{array}$ & $\begin{array}{l}\text { - Survey question } \\
\text { post-SHP score } \\
\text { improvements (p- } \\
\text { value not given for } \\
\text { all questions from } \\
\text { study): } \\
\text { - Q1: Surgery SSI }\end{array}$ & $\begin{array}{l}\text { - Worth to Practice: } \\
\text { - LOE: USPSTF } \\
\text { Grade B and } \\
\text { Moderate Strength } \\
\text { of Evidence } \\
\text { - Strengths: A lot of } \\
\text { results were }\end{array}$ \\
\hline
\end{tabular}




\begin{tabular}{|c|c|c|c|c|c|c|}
\hline $\begin{array}{l}\text { Author and } \\
\text { date }\end{array}$ & $\begin{array}{l}\text { Purpose \& } \\
\text { Variables }\end{array}$ & Design/Method & Sample/Setting & Data Analysis & Findings & $\begin{array}{l}\text { Worth to Practice } \\
\text { LOE } \\
\text { Strengths/Weaknesse } \\
\text { s } \\
\text { Feasibility } \\
\text { Conclusion } \\
\text { Recommendations }\end{array}$ \\
\hline & $\begin{array}{l}\text { - Post-SHP } \\
\text { survey } \\
\text { questions: } \\
\text { - Q1: I was } \\
\text { satisfied with } \\
\text { the OR to ICU } \\
\text { handoff for this } \\
\text { patient } \\
\text { - Q2: The report } \\
\text { given by the } \\
\text { surgery } \\
\text { provider was } \\
\text { satisfactory } \\
\text { - Q3: The report } \\
\text { given by the } \\
\text { anaesthesiology } \\
\text { provider was } \\
\text { satisfactory } \\
\text { - Q4: I could } \\
\text { hear all of the } \\
\text { report } \\
\text { - Q5: I received } \\
\text { information }\end{array}$ & $\begin{array}{l}\text { presentations, } \\
\text { booklets, and } \\
\text { visual aids } \\
\text { 5-point Likert } \\
\text { scale }\end{array}$ & $\begin{array}{l}\text { - Number of } \\
\text { total surveys } \\
\text { completed not } \\
\text { provided, and } \\
\text { breakdown of } \\
\text { providers } \\
\text { completing } \\
\text { surveys not } \\
\text { included } \\
\text { - Pts from OR to } \\
\text { cardiac ICU in } \\
\text { South African } \\
\text { tertiary } \\
\text { hospital } \\
\text { - Pt } \\
\text { demographics } \\
\text { not provided }\end{array}$ & $\begin{array}{l}\text { used in place of } \\
\text { ANOVA or t- } \\
\text { test because } \\
\text { distributions of } \\
\text { the continuous } \\
\text { valued variables } \\
\text { were non- } \\
\text { normal } \\
\text { - Statistical } \\
\text { significance set } \\
\text { at } p<0.05\end{array}$ & $\begin{array}{l}\text { - Q2: RN SSI } \\
\text { - Q3: RN SSI } \\
\text { - Q4: RN and } \\
\text { anesthesia SSI } \\
\text { - Q5: RN and } \\
\text { anesthesia SSI } \\
\text { - Q6: RN and } \\
\text { anesthesia SSI } \\
\text { - Q7: No SSI } \\
\text { - Q8: RN and } \\
\text { anesthesia SSI } \\
\text { - Q9: RN and } \\
\text { anesthesia SSI }\end{array}$ & $\begin{array}{l}\text { collected for } \\
\text { surveys, and results } \\
\text { were from } \\
\text { anesthesia, surgery, } \\
\text { and ICU RNs. } \\
\text { Funding and } \\
\text { conflicts of interest } \\
\text { included. } \\
\text { - Weaknesses: } \\
\text { Unclear of source of } \\
\text { SHP. Lack of pre- } \\
\text { SHP surveys and } \\
\text { lack of specific data } \\
\text { related to survey } \\
\text { results. Total } \\
\text { handovers observed } \\
\text { not mentioned. } \\
\text { Blinding and } \\
\text { selection bias } \\
\text { concerns due to the } \\
\text { nature of the study } \\
\text { (surveys and pre- } \\
\text { implementation } \\
\text { education alert }\end{array}$ \\
\hline
\end{tabular}




\begin{tabular}{|c|c|c|c|c|c|c|}
\hline $\begin{array}{l}\text { Author and } \\
\text { date }\end{array}$ & $\begin{array}{l}\text { Purpose \& } \\
\text { Variables }\end{array}$ & Design/Method & Sample/Setting & Data Analysis & Findings & $\begin{array}{l}\text { Worth to Practice } \\
\text { LOE } \\
\text { Strengths/Weaknesse } \\
\text { s } \\
\text { Feasibility } \\
\text { Conclusion } \\
\text { Recommendations }\end{array}$ \\
\hline & $\begin{array}{l}\text { about potential } \\
\text { problems that } \\
\text { could arise in } \\
\text { this patient } \\
\text { - Q6: I received } \\
\text { information } \\
\text { about things I } \\
\text { need to follow } \\
\text { up } \\
\text { - Q7: The } \\
\text { physical act of } \\
\text { transferring } \\
\text { monitors and } \\
\text { equipment went } \\
\text { smoothly } \\
\text { - Q8: It was clear } \\
\text { when the } \\
\text { handoff started } \\
\text { and ended } \\
\text { Q9: I received } \\
\text { guidance on } \\
\text { what to do if }\end{array}$ & & & & & $\begin{array}{l}\text { participants of } \\
\text { design). } \\
\text { - Feasibility: This } \\
\text { study is greatly } \\
\text { feasible for basically } \\
\text { any ICU, especially } \\
\text { those lacking a SHP. } \\
\text { It comes at little cost } \\
\text { financially for an } \\
\text { institution and } \\
\text { education prior to } \\
\text { implementation } \\
\text { would not require a } \\
\text { great number of } \\
\text { resources or time. } \\
\text { - Conclusion: This } \\
\text { study shows } \\
\text { statistically } \\
\text { significant } \\
\text { improvements in } \\
\text { providers' } \\
\text { satisfaction with } \\
\text { numerous handover } \\
\text { areas after SHP }\end{array}$ \\
\hline
\end{tabular}




\begin{tabular}{|c|c|c|c|c|c|c|}
\hline $\begin{array}{l}\text { Author and } \\
\text { date }\end{array}$ & $\begin{array}{l}\text { Purpose \& } \\
\text { Variables }\end{array}$ & Design/Method & Sample/Setting & Data Analysis & Findings & $\begin{array}{l}\text { Worth to Practice } \\
\text { LOE } \\
\text { Strengths/Weaknesse } \\
\text { s } \\
\text { Feasibility } \\
\text { Conclusion } \\
\text { Recommendations }\end{array}$ \\
\hline & $\begin{array}{l}\text { certain problems } \\
\text { arise }\end{array}$ & & & & & $\begin{array}{l}\text { implementation. } \\
\text { Overall, this was a } \\
\text { well-conducted and } \\
\text { readable study and } \\
\text { could be similarly } \\
\text { conducted in most } \\
\text { ICUs. } \\
\text { - Recommendations: } \\
\text { Improved strategies } \\
\text { need to be } \\
\text { considered for } \\
\text { increasing survey } \\
\text { participation. } \\
\text { Perhaps an RCT-like } \\
\text { study could be } \\
\text { constructed to } \\
\text { simultaneously } \\
\text { assess and compare } \\
\text { satisfaction with the } \\
\text { handover process } \\
\text { between teams using } \\
\text { an SHP and teams } \\
\text { not using one. This } \\
\text { way satisfaction }\end{array}$ \\
\hline
\end{tabular}




\begin{tabular}{|c|c|c|c|c|c|c|}
\hline $\begin{array}{l}\text { Author and } \\
\text { date }\end{array}$ & $\begin{array}{l}\text { Purpose \& } \\
\text { Variables }\end{array}$ & Design/Method & Sample/Setting & Data Analysis & Findings & $\begin{array}{l}\text { Worth to Practice } \\
\text { LOE } \\
\text { Strengths/Weaknesse } \\
\text { s } \\
\text { Feasibility } \\
\text { Conclusion } \\
\text { Recommendations }\end{array}$ \\
\hline & & & & & & $\begin{array}{l}\text { could be compared } \\
\text { over the exact same } \\
\text { time period. }\end{array}$ \\
\hline $\begin{array}{l}\text { Lane-Fall et } \\
\text { al., (2020) }\end{array}$ & $\begin{array}{l}\text { - Assess } \\
\text { effectiveness of } \\
\text { SHP checklist } \\
\text { on decreasing } \\
\text { information } \\
\text { omissions } \\
\text { - Survey } \\
\text { questions } \\
\text { asked: } \\
\text { - Q1: How often } \\
\text { do you need to } \\
\text { find other } \\
\text { clinicians to } \\
\text { clarify } \\
\text { information } \\
\text { - Q2: Do you } \\
\text { find the new } \\
\text { SHP acceptable } \\
\text { - Q3: Does the } \\
\text { new SHP make }\end{array}$ & $\begin{array}{l}\text { - Parallel mixed- } \\
\text { methods } \\
\text { observation } \\
\text { study } \\
\text { evaluating } \\
\text { quantitative and } \\
\text { qualitative data } \\
\text { - Pre- } \\
\text { intervention } \\
\text { conducted } \\
\text { interviews and } \\
\text { focus groups to } \\
\text { assess clinician } \\
\text { attitude towards } \\
\text { current } \\
\text { handover } \\
\text { procedure to } \\
\text { develop SHP } \\
\text { - Posters placed } \\
\text { in ICU as }\end{array}$ & $\begin{array}{l}\text { - } 68 \text { pre- and } 97 \\
\text { post-SHP } \\
\text { intervention } \\
\text { observations } \\
\text { - } 132 \text { pre-SHP } \\
\text { surveys and } \\
160 \text { post- } \\
\text { survey } \\
\text { responses } \\
\text { - Conducted in } 2 \\
\text { adult mixed- } \\
\text { ICU } \\
\text { Philadelphia, } \\
\text { PA academic } \\
\text { tertiary } \\
\text { hospitals } \\
\text { - Pt } \\
\text { demographics } \\
\text { not listed }\end{array}$ & $\begin{array}{l}\text { - Chi-square } \\
\text { tests were used } \\
\text { to compare } \\
\text { survey } \\
\text { responses } \\
\text { before and } \\
\text { after } \\
\text { implementation } \\
\text { for Q1 } \\
\text { - Post-SHP } \\
\text { based on } \\
\text { frequencies (no } \\
\text { p-value or } \\
\text { comparison) }\end{array}$ & $\begin{array}{l}\text { - Q1 pre and post } \\
\text { comparison and } \\
\text { Q2-Q4 post-SHP } \\
\text { only data } \\
\text { - Q1: Improved } \\
\text { (decreased) from } \\
81 \%(\mathrm{n}=74) \text { to } \\
56 \%(\mathrm{n}=68) \\
(\mathrm{p}<0.001) \\
\text { - } 2: 89.5 \% \\
(\mathrm{n}=136) \\
\text { - } \mathrm{Q} 3: 68.7 \% \\
(\mathrm{n}=107)\end{array}$ & $\begin{array}{l}\text { - Worth to Practice: } \\
\text { Valuable due to } \\
\text { improvement in role } \\
\text { identification and } \\
\text { perceived } \\
\text { improvement in } \\
\text { patient care } \\
\text { - LOE: USPSTF } \\
\text { Grade B and } \\
\text { Moderate Strength } \\
\text { of Evidence } \\
\text { - Strengths: Example } \\
\text { SHP provided. } \\
\text { Implemented SHP in } \\
\text { two sites for study. } \\
\text { A large number of } \\
\text { observations were } \\
\text { performed between } \\
\text { the two study sites. }\end{array}$ \\
\hline
\end{tabular}




\begin{tabular}{|c|c|c|c|c|c|c|}
\hline $\begin{array}{l}\text { Author and } \\
\text { date }\end{array}$ & $\begin{array}{l}\text { Purpose \& } \\
\text { Variables }\end{array}$ & Design/Method & Sample/Setting & Data Analysis & Findings & $\begin{array}{l}\text { Worth to Practice } \\
\text { LOE } \\
\text { Strengths/Weaknesse } \\
\text { s } \\
\text { Feasibility } \\
\text { Conclusion } \\
\text { Recommendations }\end{array}$ \\
\hline & $\begin{array}{l}\text { patient care } \\
\text { better or much } \\
\text { better } \\
\text { - Q4: Does the } \\
\text { new SHP make } \\
\text { patient care } \\
\text { worse or much } \\
\text { worse }\end{array}$ & $\begin{array}{l}\text { reference and } \\
\text { 1-month spent } \\
\text { training ICU } \\
\text { staff on } \\
\text { implementation } \\
\text { - Surveys } \\
\text { collected were } \\
\text { anonymous \& } \\
\text { web-based }\end{array}$ & & & & $\begin{array}{l}\text { - Weaknesses: } \\
\text { Limited data } \\
\text { provided on specific } \\
\text { survey details and } \\
\text { statistics. Actual } \\
\text { survey questions not } \\
\text { included. Blinding } \\
\text { and selection bias } \\
\text { concerns due to the } \\
\text { nature of the study } \\
\text { (surveys and pre- } \\
\text { implementation } \\
\text { education alert } \\
\text { participants of } \\
\text { design). } \\
\text { - Feasibility: This } \\
\text { study is feasible for } \\
\text { implementation. } \\
\text { Conducting a two- } \\
\text { site study would } \\
\text { require additional } \\
\text { work compared to } \\
\text { one site, but } \\
\text { feasibility }\end{array}$ \\
\hline
\end{tabular}




\begin{tabular}{|c|c|c|c|c|c|c|}
\hline $\begin{array}{l}\text { Author and } \\
\text { date }\end{array}$ & $\begin{array}{l}\text { Purpose \& } \\
\text { Variables }\end{array}$ & Design/Method & Sample/Setting & Data Analysis & Findings & $\begin{array}{l}\text { Worth to Practice } \\
\text { LOE } \\
\text { Strengths/Weaknesse } \\
\text { s } \\
\text { Feasibility } \\
\text { Conclusion } \\
\text { Recommendations }\end{array}$ \\
\hline & & & & & & $\begin{array}{l}\text { - Conclusion: This } \\
\text { study shows } \\
\text { improvement in key } \\
\text { areas such as the } \\
\text { ability to find } \\
\text { clinicians after } \\
\text { implementation and } \\
\text { improved perception } \\
\text { of patient care. If } \\
\text { clinicians perceive } \\
\text { patient care } \\
\text { improvement, then } \\
\text { perception may carry } \\
\text { over to actual patient } \\
\text { care improvements } \\
\text { - Recommendations: } \\
\text { More survey } \\
\text { questions should be } \\
\text { asked like in other } \\
\text { studies and more } \\
\text { survey statistics } \\
\text { should be included } \\
\text { in order to perceive a } \\
\text { wide range of }\end{array}$ \\
\hline
\end{tabular}




\begin{tabular}{|c|c|c|c|c|c|c|}
\hline $\begin{array}{l}\text { Author and } \\
\text { date }\end{array}$ & $\begin{array}{l}\text { Purpose \& } \\
\text { Variables }\end{array}$ & Design/Method & Sample/Setting & Data Analysis & Findings & $\begin{array}{l}\text { Worth to Practice } \\
\text { LOE } \\
\text { Strengths/Weaknesse } \\
\text { s } \\
\text { Feasibility } \\
\text { Conclusion } \\
\text { Recommendations }\end{array}$ \\
\hline & & & & & & $\begin{array}{l}\text { clinician feelings } \\
\text { toward SHP } \\
\text { implementation. } \\
\text { Another potential } \\
\text { study could assess } \\
\text { the same satisfaction } \\
\text { surveys between two } \\
\text { sites with one site } \\
\text { that has no SHP and } \\
\text { another that does. }\end{array}$ \\
\hline $\begin{array}{c}\text { - Gleicher et } \\
\text { al., (2017) }\end{array}$ & $\begin{array}{l}\text { - Improve post- } \\
\text { operative } \\
\text { handover } \\
\text { information } \\
\text { transfer by } \\
\text { developing and } \\
\text { implementing a } \\
\text { SHP } \\
\text { - Post-SHP } \\
\text { implementation } \\
\text { Questions: } \\
\text { - Q1: The new } \\
\text { SHP improved }\end{array}$ & $\begin{array}{l}\text { - Prospective QI } \\
\text { observational } \\
\text { study } \\
\text { - Project headed } \\
\text { by a team of } \\
\text { physicians and } \\
\text { nurses } \\
\text { - SHP developed } \\
\text { after literature } \\
\text { review and in- } \\
\text { person } \\
\text { communication } \\
\text { between }\end{array}$ & $\begin{array}{l}\text { - N=6 pre-SHP } \\
\text { and } \mathrm{n}=31 \text { post- } \\
\text { SHP handovers } \\
\text { observed } \\
\text { - } \mathrm{N}=36 \text { post- } \\
\text { SHP surveys } \\
\text { - Adult CVICU } \\
\text { post-op } \\
\text { patients in a } \\
\text { tertiary care } \\
\text { hospital }\end{array}$ & $\begin{array}{l}\text { - Survey results } \\
\text { were based on } \\
\text { post-SHP } \\
\text { frequencies (no } \\
\text { p-values or } \\
\text { pre/post } \\
\text { comparisons) }\end{array}$ & $\begin{array}{l}\text { - Post-SHP } \\
\text { implementation } \\
\text { survey results: } \\
\text { - Q1: } 91 \% \text { agreed } \\
\text { - Q2: 91\% agreed } \\
\text { - Q3: 3\% agreed } \\
\text { - Q4: 97\% agreed }\end{array}$ & $\begin{array}{l}\text { - Worth to Practice: } \\
\text { Valuable to any OR } \\
\text { to ICU facility } \\
\text { lacking a SHP } \\
\text { - LOE: USPSTF } \\
\text { Grade B and } \\
\text { Moderate Strength } \\
\text { of Evidence } \\
\text { - Strengths: Example } \\
\text { SHP provided. SHP } \\
\text { was actively revised } \\
\text { as it was } \\
\text { incorporated in the }\end{array}$ \\
\hline
\end{tabular}




\begin{tabular}{|c|c|c|c|c|c|c|}
\hline $\begin{array}{l}\text { Author and } \\
\text { date }\end{array}$ & $\begin{array}{l}\text { Purpose \& } \\
\text { Variables }\end{array}$ & Design/Method & Sample/Setting & Data Analysis & Findings & $\begin{array}{l}\text { Worth to Practice } \\
\text { LOE } \\
\text { Strengths/Weaknesse } \\
\text { s } \\
\text { Feasibility } \\
\text { Conclusion } \\
\text { Recommendations }\end{array}$ \\
\hline & $\begin{array}{l}\text { the quality of } \\
\text { information } \\
\text { transferred } \\
\text { during } \\
\text { handover } \\
\text { - Q2: The new } \\
\text { SHP improved } \\
\text { teamwork } \\
\text { between OR } \\
\text { and CVICU } \\
\text { team members } \\
\text { Q3: The new } \\
\text { SHP interfered } \\
\text { with } \\
\text { caregivers' } \\
\text { ability to } \\
\text { provide timely } \\
\text { patient care } \\
\text { - Overall, new } \\
\text { SHP is a } \\
\text { valuable } \\
\text { addition to the } \\
\text { cardiac surgery } \\
\text { program }\end{array}$ & $\begin{array}{l}\text { researchers and } \\
\text { OR staff and } \\
\text { CVICU staff } \\
\text { and nurses } \\
\text { - After pt } \\
\text { attachment to } \\
\text { ventilator, } \\
\text { formal timeout } \\
\text { started and } \\
\text { begins with } \\
\text { introductions } \\
\text { - Surgeon briefly } \\
\text { describes } \\
\text { procedure, } \\
\text { surgical } \\
\text { difficulties, } \\
\text { post-op } \\
\text { concerns } \\
\text { - Anesthesia fills } \\
\text { out checklist } \\
\text { for written } \\
\text { handover and to } \\
\text { guide verbal if } \\
\text { inclined }\end{array}$ & $\begin{array}{l}\text { Patient } \\
\text { demographics } \\
\text { not included }\end{array}$ & & & $\begin{array}{l}\text { CVICU during the } \\
\text { study. Surveys were } \\
\text { completed by } \\
\text { multidisciplinary } \\
\text { handover team. } \\
\text { - Weaknesses: } \\
\text { Survey results had } \\
\text { no statistical } \\
\text { analysis. Lack of } \\
\text { pre-SHP surveys. } \\
\text { Only } 36 \text { surveys } \\
\text { were completed. } \\
\text { Blinding and } \\
\text { selection bias } \\
\text { concerns due to the } \\
\text { nature of the study } \\
\text { (surveys and pre- } \\
\text { implementation } \\
\text { education alert } \\
\text { participants of } \\
\text { design). } \\
\text { - Feasibility: Feasible } \\
\text { due to low cost, } \\
\text { relatively low }\end{array}$ \\
\hline
\end{tabular}




\begin{tabular}{|c|c|c|c|c|c|c|}
\hline $\begin{array}{l}\text { Author and } \\
\text { date }\end{array}$ & $\begin{array}{l}\text { Purpose \& } \\
\text { Variables }\end{array}$ & Design/Method & Sample/Setting & Data Analysis & Findings & $\begin{array}{l}\text { Worth to Practice } \\
\text { LOE } \\
\text { Strengths/Weaknesse } \\
\text { s } \\
\text { Feasibility } \\
\text { Conclusion } \\
\text { Recommendations }\end{array}$ \\
\hline & & $\begin{array}{l}\text { - Concluded with } \\
\text { ability to ask } \\
\text { clarification } \\
\text { questions, } \\
\text { readback } \\
\text { outlining } \\
\text { current } \\
\text { med/surg issues }\end{array}$ & & & & $\begin{array}{l}\text { resource input } \\
\text { requirement, and } \\
\text { ease of conducting } \\
\text { electronic surveys. } \\
\text { - Conclusion: This } \\
\text { particular study } \\
\text { agrees with most } \\
\text { literature that SHPs } \\
\text { improve staff } \\
\text { teamwork, } \\
\text { communication, and } \\
\text { overall satisfaction } \\
\text { with the handover } \\
\text { process. } \\
\text { - Recommendations: } \\
\text { Future studies should } \\
\text { conduct more } \\
\text { thorough statistical } \\
\text { analyses of survey } \\
\text { results and increase } \\
\text { the number of } \\
\text { completed surveys. } \\
\text { Also, surveys could } \\
\text { incorporate more }\end{array}$ \\
\hline
\end{tabular}




\begin{tabular}{|l|l|l|l|l|l|l|}
\hline $\begin{array}{l}\text { Author and } \\
\text { date }\end{array}$ & $\begin{array}{l}\text { Purpose \& } \\
\text { Variables }\end{array}$ & Design/Method & Sample/Setting & Data Analysis & Findings & $\begin{array}{l}\text { Worth to Practice } \\
\text { LOE } \\
\text { Strengths/Weaknesse } \\
\text { s } \\
\text { Feasibility } \\
\text { Conclusion } \\
\text { Recommendations }\end{array}$ \\
\hline & & & & & \\
& & & & & questions in order to \\
assess other \\
perceptions and \\
satisfactions or with \\
SHPs newly \\
incorporated into \\
hospital units.
\end{tabular}

Note. Table modified from Melnyk, B. M., \& Fineout-Overholt, E. (2019). Evidence-based practice in nursing and healthcare: A guide to best practice (4 ${ }^{\text {th }}$ ed.). Wolters Kluwer, p. 792-793.

Legend: CSICU $=$ cardiac surgery intensive care unit, CTICU $=$ Cardiothoracic intensive care unit, CVICU $=$ Cardiovascular intensive care unit, ICU = intensive care unit, med = medical, NP = nurse practitioner, OR = operating room, post-op $=$ post-operative/postoperatively, pre-op $=$ pre-operative/pre-operatively, $\mathrm{PA}=$ physician assistant, $\mathrm{pt}=$ patient, $\mathrm{PTX}=$ patient $\operatorname{transfer}(\mathrm{s}), \mathrm{QI}=\mathrm{quality}$ improvement, $\mathrm{RT}=$ respiratory therapist, $\mathrm{SHP}=$ standardized handover protocol, $\mathrm{SICU}=$ surgical intensive care unit, $\mathrm{SSI}=$ statistically significant improvement, surg $=$ surgical, $\mathrm{THOR}=$ The handover report, U.S. $=$ United States, VA $=$ Veterans Affair 


\section{Appendix B}

\section{Figure 1}

\section{Pre- and Post-implementation Questionnaire}

Q1 What is your job role?

Anesthesia provider (M.D. or CRNA) (1)

SICU Registered Nurse (2)

Surgery Service Member (General Surgery, trauma, orthopedics) (3)

Q2 Overall, I am satisfied with the quality of the OR to SICU bedside patient handover report process.

\begin{tabular}{|c|c|c|c|c|c|}
\hline & $\begin{array}{c}\text { Strongly disagree } \\
\text { (1) }\end{array}$ & $\begin{array}{c}\text { Somewhat disagree } \\
\text { (2) }\end{array}$ & $\begin{array}{l}\text { Neither agree nor } \\
\text { disagree (3) }\end{array}$ & Somewhat agree (4) & Strongly agree (5) \\
\hline $\begin{array}{l}\text { Please choose an } \\
\text { option to the right } \\
\text { (1) }\end{array}$ & & & & & \\
\hline
\end{tabular}

Q3 It is clear when the bedside handover report begins and ends.

\begin{tabular}{c|ccccc} 
& $\begin{array}{c}\text { Strongly disagree } \\
(1)\end{array}$ & $\begin{array}{c}\text { Somewhat disagree } \\
\text { (2) }\end{array}$ & $\begin{array}{c}\text { Neither agree nor } \\
\text { disagree (3) }\end{array}$ & Somewhat agree (4) & Strongly agree (5) \\
\hline $\begin{array}{c}\text { Please choose an } \\
\text { option to the right } \\
(1)\end{array}$ & & & &
\end{tabular}

Q4 Interruptions frequently impair the bedside handover report.

\begin{tabular}{|c|c|c|c|c|c|}
\hline & $\begin{array}{c}\text { Strongly disagree } \\
\text { (1) }\end{array}$ & $\begin{array}{c}\text { Somewhat disagree } \\
\text { (2) }\end{array}$ & $\begin{array}{l}\text { Neither agree nor } \\
\text { disagree (3) }\end{array}$ & Somewhat agree (4) & Strongly agree (5) \\
\hline $\begin{array}{l}\text { Please choose an } \\
\text { option to the right } \\
\text { (1) }\end{array}$ & & & & & \\
\hline
\end{tabular}

Q5 I am able to hear all of the bedside handover report.

\begin{tabular}{|c|c|c|c|c|c|}
\hline & $\begin{array}{c}\text { Strongly disagree } \\
\text { (1) }\end{array}$ & $\begin{array}{l}\text { Somewhat disagree } \\
\text { (2) }\end{array}$ & $\begin{array}{l}\text { Neither agree nor } \\
\text { disagree (3) }\end{array}$ & Somewhat agree (4) & Strongly agree (5) \\
\hline $\begin{array}{l}\text { Please choose an } \\
\text { option to the right } \\
\text { (1) }\end{array}$ & & & & & \\
\hline
\end{tabular}


Q6 I am satisfied with the information that is communicated concerning the patient and procedure during the bedside handover report.

\begin{tabular}{|c|c|c|c|c|c|}
\hline & $\begin{array}{c}\text { Strongly disagree } \\
\text { (1) }\end{array}$ & $\begin{array}{c}\text { Somewhat disagree } \\
\text { (2) }\end{array}$ & $\begin{array}{l}\text { Neither agree nor } \\
\text { disagree (3) }\end{array}$ & Somewhat agree (4) & Strongly agree (5) \\
\hline $\begin{array}{l}\text { Please choose an } \\
\text { option to the right } \\
\text { (1) }\end{array}$ & & & & & \\
\hline
\end{tabular}

Q7 I am often unable to find or identify the appropriate staff member(s) needed to conduct a thorough bedside handover report (receiving bedside nurse, surgery member, or anesthesia provider).

\begin{tabular}{|c|c|c|c|c|c|}
\hline & $\begin{array}{c}\text { Strongly disagree } \\
\text { (1) }\end{array}$ & $\begin{array}{c}\text { Somewhat disagree } \\
\text { (2) }\end{array}$ & $\begin{array}{l}\text { Neither agree nor } \\
\text { disagree (3) }\end{array}$ & Somewhat agree (4) & Strongly agree (5) \\
\hline $\begin{array}{l}\text { Please choose an } \\
\text { option to the right } \\
\text { (1) }\end{array}$ & & & & & \\
\hline
\end{tabular}

Q8 Please type any suggestions for handover report improvements or other discontents with the current OR to SICU patient handover bedside report process.

Note. The survey was created using Qualtrics (2020). The post-survey was identical to the presurvey. 
Appendix C

Figure 2

Standardized Handover Process Checklist

\section{Operating Room to Surgical ICU Patient Handover Checklist}

\section{Huddle Up}

1. Surgery member, Anesthesia, \& Bedside RN present \& identified

2. Once in huddle, receiving bedside RN says "Ready for report"

3. No outside interruptions during report (unless emergency arises)

\section{Surgical Report}

1. Surgery performed

2. Placement of drains, devices, "hardware"

3. Special instructions/Anticipated future procedures

4. Immediate patient concerns

5. Bedside RN asks for clarification/Asks questions if needed

6. Surgery report complete.

\section{Anesthesia Report}

1. Airway/Breathing/Ventilator settings/ABG concerns

2. IV drips/Last vasopressor(s) \& dose(s)/BP or HR instability

3. I\&O: Blood products/Fluid Boluses/EBL/Estimated urine output

4. Lines/Access/Monitoring Devices \& their locations

5. Sedation/Analgesia \& Last dose(s)

6. Technique: General anesthesia, regional, neuraxial, etc.

7. Paralytic status: Paralyzed/Reversed

8. Immediate patient concerns

9. Bedside RN asks for clarification/Asks questions if needed

10. Anesthesia report complete

Note. Survey created using Canva (2020). 


\section{Appendix D}

\section{Table 2}

Budget Plan

\begin{tabular}{|c|c|c|}
\hline Budget Categories & Personal Funds & Organizational Contributions \\
\hline ADMINISTRATIVE COSTS & $\$ 0$ & $\$ 0$ \\
\hline \multicolumn{3}{|l|}{ Administrative justification: } \\
\hline MARKETING & $\$ 0$ & $\$ 0$ \\
\hline \multicolumn{3}{|c|}{ Marketing justification: No plans other than educational emails and surveys sent to staff. } \\
\hline $\begin{array}{l}\text { EDUCATIONAL } \\
\text { MATERIALS/ INCENTIVES }\end{array}$ & $\$ 0$ & $\$ 0$ \\
\hline \multicolumn{3}{|c|}{$\begin{array}{l}\text { Educational Materials/Incentives justification: Educational material was typed and sent to } \\
\text { participants' emails. }\end{array}$} \\
\hline $\begin{array}{l}\text { HOSPITALITY (food, room } \\
\text { rentals, etc.) }\end{array}$ & $\$ 0$ & $\$ 0$ \\
\hline \multicolumn{3}{|l|}{ Hospitality justification: N/A } \\
\hline $\begin{array}{l}\text { PROJECT SUPPLIES (office } \\
\text { supplies, postage, printing, etc.) }\end{array}$ & $\$ 100$ & $\$ 0$ \\
\hline \multicolumn{3}{|c|}{$\begin{array}{l}\text { Project supplies justification: The organization has email and internet access freely available } \\
\text { to employees. } \$ 100 \text { for printer paper, printer ink, and laminating supplies at a local business. }\end{array}$} \\
\hline TRAVEL EXPENSES & $\$ 0$ & $\$ 0$ \\
\hline \multicolumn{3}{|l|}{ Travel expenses justification: N/A } \\
\hline TOTALS & $\$ 0$ & $\$ 100$ \\
\hline
\end{tabular}


71

Appendix E

Figure 3

Evidence of Key Site Support

Key Site Support Verification

This document is to verify that Jacob Key, a West Virginia University Doctor of Nursing Practice Nurse Anesthetist Program student, has permission to conduct the proposed project regarding the standardization of patient handovers from the Operating Room to the Surgical Intensive Care Unit at West Virginia University Medicine's Ruby Memorial Hospital. The project conducted by the student will receive approval from the West Virginia University Institutional Review Board before initiation. The project is also being overseen by the student's faculty of record, Dr. Mike Frame, DMPNA, APRN, CRNA.

icu Manager's name: Miranda N Vo um

ICU Manager's signature:

Miranda

Date:

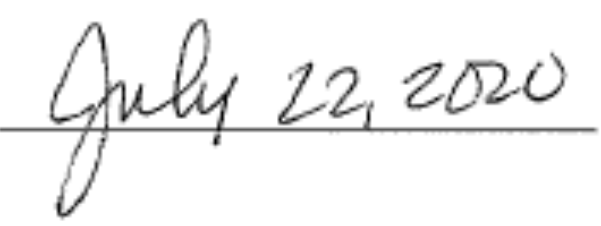




\section{Appendix F}

Table 3

Project Timeline

\section{GANTT CHART for SHP From OR to SICU: QI Project}

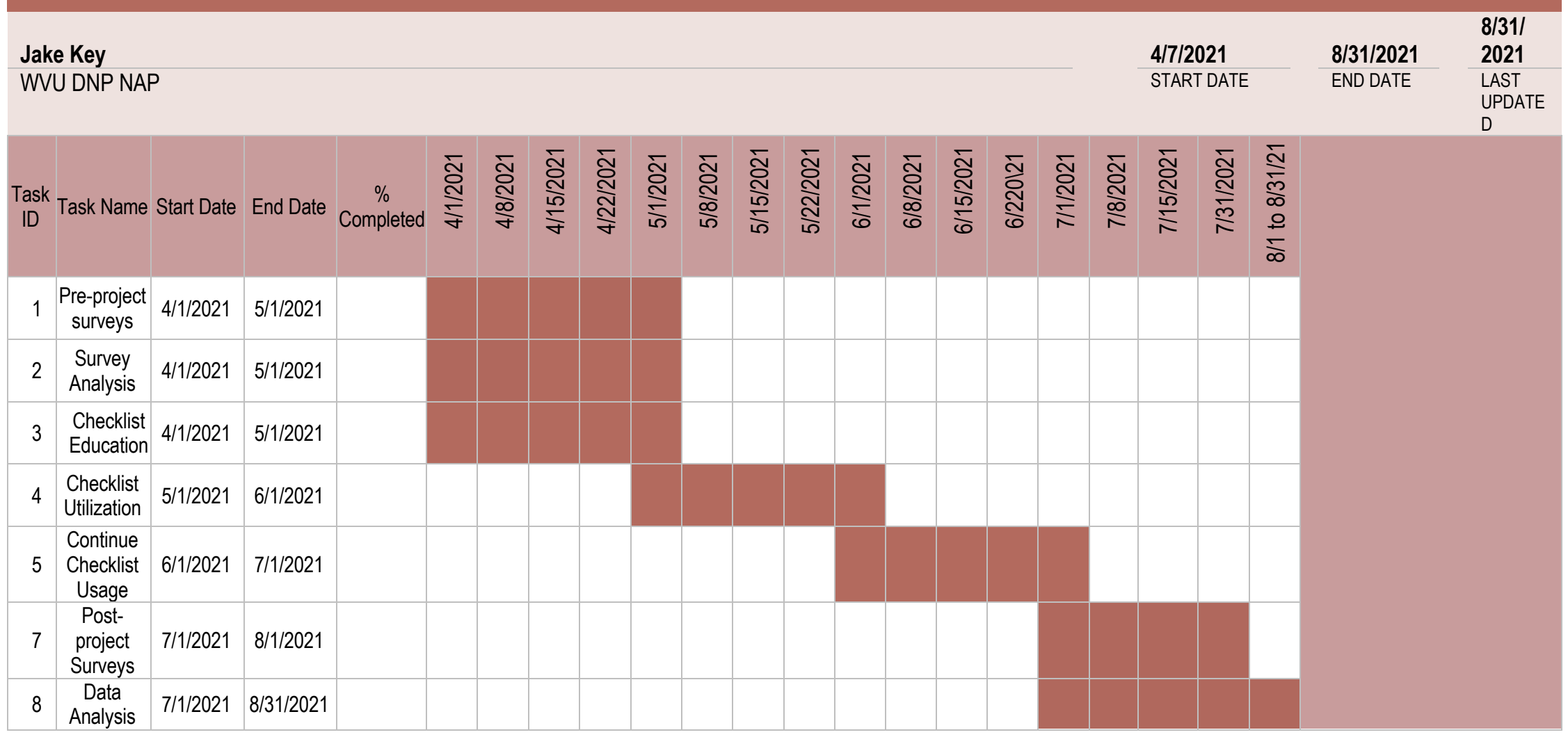




\section{Appendix G}

\section{Figure 4}

In-person and Email Education

The purpose of this short, concise standardized checklist is to eliminate distractions and interruptions, minimize parallel conversations, reduce team member absence, and improve team communication and critical information sharing during bedside handover reports throughout post-operative OR to SICU patient transfers. It is critical that an anesthesia member, surgery member, and the bedside $\mathrm{RN}$ assuming care of the patient are in attendance for bedside handover report. Report should begin immediately upon the patient's arrival to his/her SICU room and once all three report members are present. The receiving bedside nurse must identify his or herself so that report may be initiated. The checklist should be used to help guide the report, and adjustments to the report sequence may be made as necessary for each handover. The admitting $\mathrm{RN}$ is encouraged to ask questions at the end of the surgery and anesthesia portions of the report to ensure clarity.

Charge, acuity, and/or neighboring nurses and clinical associates may tend to patient tasks during handovers to allow bedside receiving nurses to immediately begin bedside report with the surgeon and anesthesia provider. A laminated report checklist will be placed in each SICU patient room in an area that is easily visible to all staff. See the email attachment for a visualization of the actual report checklist to be utilized during patient handovers. Please utilize the checklist to steer report during each handover involving orthopedic, general surgery, and trauma service OR to SICU patient transfers. Participation in this project is entirely voluntary, and anonymity will be maintained throughout survey result collection for those that participate. 
Thank you for taking the time to read this email and participating in this important quality improvement project. 


\section{Appendix H}

\section{Table 4}

\section{SICU RN Survey Results Comparison}

\begin{tabular}{|c|c|c|c|c|}
\hline & $\begin{array}{l}\text { Question 2: Overall I am satisfied with the } \\
\text { quality of the OR to SICU bedside patient } \\
\text { handover report process }\end{array}$ & $\begin{array}{r}\text { SICU RN } \\
\text { Pre-survey } \\
\text { Response \# }\end{array}$ & $\begin{array}{r}\text { SICU RN } \\
\text { Post-survey } \\
\text { Response \# }\end{array}$ & $\begin{array}{l}\text { Question } 2 \\
\text { p-value }\end{array}$ \\
\hline 1 & Strongly disagree & 0 & 0 & 0.041 \\
\hline 2 & Somewhat disagree & 9 & 3 & \\
\hline 3 & Neither agree nor disagree & 7 & 6 & \\
\hline 4 & Somewhat agree & 7 & 6 & \\
\hline \multirow[t]{3}{*}{5} & Strongly agree & 0 & 5 & \\
\hline & Mean & 2.91 & 3.57 & \\
\hline & $\begin{array}{l}\text { Question 3: It is clear when the bedside } \\
\text { handover report begins and ends }\end{array}$ & $\begin{array}{r}\text { SICU RN } \\
\text { Pre-survey } \\
\text { Response \# }\end{array}$ & $\begin{array}{r}\text { SICU RN } \\
\text { Post-survey } \\
\text { Response \# }\end{array}$ & $\begin{array}{r}\text { Question } 3 \\
\text { p-value }\end{array}$ \\
\hline 1 & Strongly disagree & 0 & 0 & 0.107 \\
\hline 2 & Somewhat disagree & 10 & 3 & \\
\hline 3 & Neither agree nor disagree & 3 & 8 & \\
\hline 4 & Somewhat agree & 10 & 6 & \\
\hline \multirow[t]{3}{*}{5} & Strongly agree & 0 & 4 & \\
\hline & Mean & 3.00 & 3.52 & \\
\hline & $\begin{array}{l}\text { Question 4: Interruptions frequently } \\
\text { impair the bedside handover report }\end{array}$ & $\begin{array}{r}\text { SICU RN } \\
\text { Pre-survey } \\
\text { Response \# }\end{array}$ & $\begin{array}{r}\text { SICU RN } \\
\text { Post-survey } \\
\text { Response \# }\end{array}$ & $\begin{array}{r}\text { Question } 4 \\
\text { p-value }\end{array}$ \\
\hline 1 & Strongly disagree & 0 & 1 & 0.074 \\
\hline 2 & Somewhat disagree & 1 & 0 & \\
\hline 3 & Neither agree nor disagree & 2 & 0 & \\
\hline 4 & Somewhat agree & 12 & 7 & \\
\hline \multirow[t]{2}{*}{5} & Strongly agree & 8 & 13 & \\
\hline & Mean & 4.17 & 4.48 & \\
\hline
\end{tabular}


Question 5: I am able to hear all of the bedside handover report

SICU RN

1

2

3

4

5

Mean

Question 6: I am satisfied with the information that is communicated concerning the patient and the procedure during the bedside handover report

1

2

3

4

5

Mean

Question 7: I am often unable to find or identify the appropriate staff member(s) needed to conduct a thorough bedside handover report (receiving bedside nurse, surgery member, or anesthesia provider).

1

2

3

4

5

Mean
Strongly disagree

Somewhat disagree

Neither agree nor disagree

Somewhat agree

Strongly agree

3.48

Strongly disagree

Somewhat disagree

Neither agree nor disagree

Somewhat agree

Strongly agree

$(-48$

0

5

1

12

3.7

5
Pre-survey Response \#

SICU RN

Post-survey

Response \#

Question 5

p-value

0.114

10

4

4 5

9

0

2.96

3.48

SICU RN

Pre-survey

Response \#

0

5

2

16

0

SICU RN

Pre-survey

Response \#

SICU RN

Post-survey

Response \#

Question 6

p-value

0.097

3

3

5

9

\subsection{6}

SICU RN

Post-survey

Response \#

Question 7

p-value

0.022

0 


\section{Appendix I}

\section{Table 5}

\section{Anesthesia Provider Survey Results Comparison}

\begin{tabular}{|c|c|c|c|c|}
\hline & $\begin{array}{l}\text { Question 2: Overall I am satisfied with } \\
\text { the quality of the OR to SICU bedside } \\
\text { patient handover report process }\end{array}$ & $\begin{array}{l}\text { Anesthesia } \\
\text { Pre-survey } \\
\text { Response \# }\end{array}$ & $\begin{array}{r}\text { Anesthesia } \\
\text { Post-survey } \\
\text { Response \# }\end{array}$ & $\begin{array}{l}\text { Question } \\
2 \text { p-value }\end{array}$ \\
\hline 1 & Strongly disagree & 0 & 0 & 0.031 \\
\hline 2 & Somewhat disagree & 5 & 0 & \\
\hline 3 & Neither agree nor disagree & 3 & 2 & \\
\hline 4 & Somewhat agree & 9 & 12 & \\
\hline \multirow[t]{3}{*}{5} & Strongly agree & 2 & 4 & \\
\hline & Mean & 3.42 & 4.11 & \\
\hline & $\begin{array}{l}\text { Question 3: It is clear when the } \\
\text { bedside handover report begins and } \\
\text { ends }\end{array}$ & $\begin{array}{l}\text { Anesthesia } \\
\text { Pre-survey } \\
\text { Response \# }\end{array}$ & $\begin{array}{l}\text { Anesthesia } \\
\text { Post-survey } \\
\text { Response \# }\end{array}$ & $\begin{array}{l}\text { Question } \\
3 \text { p-value }\end{array}$ \\
\hline 1 & Strongly disagree & 1 & 1 & 0.491 \\
\hline 2 & Somewhat disagree & 2 & 4 & \\
\hline 3 & Neither agree nor disagree & 6 & 2 & \\
\hline 4 & Somewhat agree & 7 & 4 & \\
\hline \multirow[t]{3}{*}{5} & Strongly agree & 3 & 7 & \\
\hline & Mean & 3.47 & 3.67 & \\
\hline & $\begin{array}{l}\text { Question 4: Interruptions frequently } \\
\text { impair the bedside handover report }\end{array}$ & $\begin{array}{l}\text { Anesthesia } \\
\text { Pre-survey } \\
\text { Response \# }\end{array}$ & $\begin{array}{l}\text { Anesthesia } \\
\text { Post-survey } \\
\text { Response \# }\end{array}$ & $\begin{array}{l}\text { Question } \\
4 \text { p-value }\end{array}$ \\
\hline 1 & Strongly disagree & 0 & 0 & 0.094 \\
\hline 2 & Somewhat disagree & 2 & 3 & \\
\hline 3 & Neither agree nor disagree & 2 & 7 & \\
\hline 4 & Somewhat agree & 8 & 4 & \\
\hline \multirow[t]{2}{*}{5} & Strongly agree & 7 & 4 & \\
\hline & Mean & 4.05 & 3.50 & \\
\hline
\end{tabular}




\begin{tabular}{|c|c|c|c|c|}
\hline & $\begin{array}{l}\text { Question 5: I am able to hear all of the } \\
\text { bedside handover report }\end{array}$ & $\begin{array}{l}\text { Anesthesia } \\
\text { Pre-survey } \\
\text { Response \# }\end{array}$ & $\begin{array}{l}\text { Anesthesia } \\
\text { Post-survey } \\
\text { Response \# }\end{array}$ & $\begin{array}{l}\text { Question } \\
5 \text { p-value }\end{array}$ \\
\hline 1 & Strongly disagree & 0 & 0 & 0.163 \\
\hline 2 & Somewhat disagree & 4 & 3 & \\
\hline 3 & Neither agree nor disagree & 3 & 3 & \\
\hline 4 & Somewhat agree & 11 & 5 & \\
\hline \multirow[t]{3}{*}{5} & Strongly agree & 1 & 7 & \\
\hline & Mean & 3.47 & 3.89 & \\
\hline & $\begin{array}{l}\text { Question 6: I am satisfied with the } \\
\text { information that is communicated } \\
\text { concerning the patient and the } \\
\text { procedure during the bedside handover } \\
\text { report }\end{array}$ & $\begin{array}{l}\text { Anesthesia } \\
\text { Pre-survey } \\
\text { Response \# }\end{array}$ & $\begin{array}{l}\text { Anesthesia } \\
\text { Post-survey } \\
\text { Response \# }\end{array}$ & $\begin{array}{l}\text { Question } \\
6 \text { p-value }\end{array}$ \\
\hline 1 & Strongly disagree & 0 & 0 & 0.024 \\
\hline 2 & Somewhat disagree & 1 & 0 & \\
\hline 3 & Neither agree nor disagree & 4 & 2 & \\
\hline 4 & Somewhat agree & 12 & 8 & \\
\hline \multirow[t]{3}{*}{5} & Strongly agree & 2 & 8 & \\
\hline & Mean & 3.79 & 4.33 & \\
\hline & $\begin{array}{l}\text { Question 7: I am often unable to find } \\
\text { or identify the appropriate staff } \\
\text { member(s) needed to conduct a } \\
\text { thorough bedside handover report } \\
\text { (receiving bedside nurse, surgery } \\
\text { member, or anesthesia provider). }\end{array}$ & $\begin{array}{l}\text { Anesthesia } \\
\text { Pre-survey } \\
\text { Response \# }\end{array}$ & $\begin{array}{l}\text { Anesthesia } \\
\text { Post-survey } \\
\text { Response \# }\end{array}$ & $\begin{array}{l}\text { Question } \\
7 \text { p-value }\end{array}$ \\
\hline 1 & Strongly disagree & 1 & 0 & 0.057 \\
\hline 2 & Somewhat disagree & 0 & 2 & \\
\hline 3 & Neither agree nor disagree & 3 & 5 & \\
\hline 4 & Somewhat agree & 7 & 9 & \\
\hline \multirow[t]{2}{*}{5} & Strongly agree & 8 & 2 & \\
\hline & Mean & 4.11 & 3.61 & \\
\hline
\end{tabular}




\section{Appendix $\mathbf{J}$}

\section{Table 6}

Surgery Service Member Survey Results Comparison

Question 2: Overall I am satisfied with the quality of the OR to SICU bedside patient handover report process

1

2

3

4

5

Mean

Question 3: It is clear when the bedside handover report begins and ends

\begin{tabular}{|r|r}
\hline 1 & $\begin{array}{r}\text { Strongly disagree } \\
\text { Somewhat disagree }\end{array}$ \\
\hline 3 & Neither agree nor disagree \\
\hline 4 & Somewhat agree \\
\hline 5 & Strongly agree \\
\hline & Mean \\
\hline & $\begin{array}{l}\text { Question 4: Interruptions frequently impair } \\
\text { the bedside handover report }\end{array}$ \\
\hline
\end{tabular}

1 Strongly disagree

2

3

4

5

5 Strongly agree

\begin{tabular}{|c|c|c|}
\hline $\begin{array}{r}\text { Surgery } \\
\text { Pre-survey } \\
\text { Response \# }\end{array}$ & $\begin{array}{r}\text { Surgery } \\
\text { Post-survey } \\
\text { Response \# }\end{array}$ & $\begin{array}{l}\text { Question } \\
2 \text { p-value }\end{array}$ \\
\hline 0 & 0 & 0.509 \\
\hline 2 & 1 & \\
\hline 1 & 1 & \\
\hline 5 & 3 & \\
\hline 2 & 3 & \\
\hline 3.70 & 4.00 & \\
\hline $\begin{array}{r}\text { Surgery } \\
\text { Pre-survey } \\
\text { Response \# }\end{array}$ & $\begin{array}{r}\text { Surgery } \\
\text { Post-survey } \\
\text { Response \# }\end{array}$ & $\begin{array}{l}\text { Question } \\
3 \text { p-value }\end{array}$ \\
\hline 0 & 0 & 0.805 \\
\hline 1 & 0 & \\
\hline 0 & 2 & \\
\hline 7 & 3 & \\
\hline 2 & 3 & \\
\hline 4.00 & 4.13 & \\
\hline $\begin{array}{r}\text { Surgery } \\
\text { Pre-survey } \\
\text { Response \# }\end{array}$ & $\begin{array}{r}\text { Surgery } \\
\text { Post-survey } \\
\text { Response \# }\end{array}$ & $\begin{array}{l}\text { Question } \\
4 \text { p-value }\end{array}$ \\
\hline 0 & 2 & 0.023 \\
\hline 1 & 2 & \\
\hline 0 & 1 & \\
\hline 4 & 2 & \\
\hline 5 & 1 & \\
\hline 4.30 & 2.75 & \\
\hline
\end{tabular}


Question 5: I am able to hear all of the bedside handover report

\begin{tabular}{|c|c|c|c|c|}
\hline & uedide randuver iepoit & Response \# & Response \# & $2 \mathrm{~h}-\mathrm{value}$ \\
\hline 1 & Strongly disagree & 0 & 0 & 0.707 \\
\hline 2 & Somewhat disagree & 2 & 2 & \\
\hline 3 & Neither agree nor disagree & 0 & 1 & \\
\hline 4 & Somewhat agree & 4 & 2 & \\
\hline \multirow[t]{3}{*}{5} & Strongly agree & 4 & 3 & \\
\hline & Mean & 4.00 & 3.75 & \\
\hline & $\begin{array}{l}\text { Question 6: I am satisfied with the } \\
\text { information that is communicated } \\
\text { concerning the patient and the procedure } \\
\text { during the bedside handover report }\end{array}$ & $\begin{array}{r}\text { Surgery } \\
\text { Pre-survey } \\
\text { Response \# }\end{array}$ & $\begin{array}{r}\text { Surgery } \\
\text { Post-survey } \\
\text { Response \# }\end{array}$ & $\begin{array}{l}\text { Question } \\
6 \mathrm{p} \text {-value }\end{array}$ \\
\hline 1 & Strongly disagree & 0 & 0 & 0.800 \\
\hline 2 & Somewhat disagree & 0 & 0 & \\
\hline 3 & Neither agree nor disagree & 0 & 1 & \\
\hline 4 & Somewhat agree & 5 & 2 & \\
\hline \multirow[t]{3}{*}{5} & Strongly agree & 5 & 5 & \\
\hline & Mean & 4.50 & 4.50 & \\
\hline & $\begin{array}{l}\text { Question 7: I am often unable to find or } \\
\text { identify the appropriate staff member(s) } \\
\text { needed to conduct a thorough bedside } \\
\text { handover report (receiving bedside nurse, } \\
\text { surgery member, or anesthesia provider). }\end{array}$ & $\begin{array}{r}\text { Surgery } \\
\text { Pre-survey } \\
\text { Response \# }\end{array}$ & $\begin{array}{r}\text { Surgery } \\
\text { Post-survey } \\
\text { Response \# }\end{array}$ & $\begin{array}{l}\text { Question } \\
7 \text { p-value }\end{array}$ \\
\hline 1 & Strongly disagree & 0 & 2 & 0.028 \\
\hline 2 & Somewhat disagree & 1 & 2 & \\
\hline 3 & Neither agree nor disagree & 0 & 1 & \\
\hline 4 & Somewhat agree & 2 & 1 & \\
\hline \multirow[t]{2}{*}{5} & Strongly agree & 7 & 2 & \\
\hline & Mean & 4.50 & 2.88 & \\
\hline
\end{tabular}




\section{Appendix K}

\section{Table 7}

Survey Respondent Free-Text Answers

\section{SICU RN Pre-Project Responses}

"Anesthesia is typically fairly consistent with their report and good at handing off. Surgical service handoff definitely needs work as sometimes patients' families will receive more info post-op from surgery than the bedside nurse does. Most times surgery gives handoff to the oncoming SICU team but that info doesn't get relayed to the nursing staff until it is placed in a note"

"Lots of times the surgeons don't even talk to the bedside nurse"

"The report from the OR call before getting to the bedside is poor. Knowing whether we need to have pressors, fluids, etc at bedside is unknown until the patient is already in the unit. We also haven't had enough hands at the bedside so the SICU primary $\mathrm{RN}$ is trying to get vitals for the anesthesia provider while trying to listen to report and make sure the patient is stable and well taken care of. I think a little synopsis/report written down and handed to the primary $\mathrm{RN}$ would also be beneficial, especially because residents and the primary service may also have questions later in the stay. I get frequently asked, "When was the last dose of paralytic and was the patient reversed?" I typically know if a reversal was given or if the patient had twitches prior to leaving the OR, but I am unable to provide when the medication was given unless I go through the anesthesia event"

"I think identifying who is giving report/receiving report from the get go will be beneficial"

"It would be nice if they make sure they give us report on a patient. Even if they are going back to the or for a simple procedure. It helps us prepare better and

\section{SICU RN Post-Project Responses}

"I was too busy to ask for a good report from the OR"

"When I took the time to use the report and ask for a good report, it worked out well"

"I liked using this to help guide report"
"I liked using the report sheet when I did use it. Sometimes I was too busy and forgot"

"Part of the time it seems our patients come out and are busy therefore taking the time to strictly pay attention to report can seem impossible. There are times when more than one person is talking in the room; it is not as 
allows us to take care of our patients appropriately and in a timely manner"

"Have the CRNA or anesthesia provider call report prior to arriving instead of the OR RN"

"Too many distractions during report, feel as if questions don't always get answered before OR staff leaves bedside, too much information thrown at you at once during the chaos of transfer. I feel there needs to be a handoff sheet that get filled out with all pertinent information regarding surgery and post op expectations."

"Sometimes we don't get report directly and it's given to the resident"

"Doing report far enough physically away from the patients bedside to let staff who are not the primary nurse get in to the patient so that report is not distracted by moving parts or delaying $\mathrm{pt}$ care/monitoring, waiting after report from both the surgical and OR staff is done to ask nurse for temperature if not already done so by other staff"

"There needs to be better communication to the nurse when the OR gives report" though we have a set time for anesthesia, the $\mathrm{RN}$, and the surgeon to give their report/ orders."

"The one day a CRNA called me from the OR to give me a full report before ending the case in the OR, and then continued to give me updates at the bedside and I felt that this was extremely helpful and a great way to communicate. The typical OR RN phone report is often lacking a lot of information that we need."

"This helped me identify who to get report from"

"In a perfect world the bedside $\mathrm{RN}$ and $\mathrm{OR}$ staff can stand off to the side and do bedside report while patient is getting established in bed by other RNs and ancillary staff but that is not always possible. Maybe add to the Passport info like drugs or blood products used, EBL etc so if there is any confusion or missed info the bedside $\mathrm{RN}$ can look at the passport for that info"

"This helped me get clearer information from the surgeons"

"I was surprised everyone was willing to give the report when I took the time to ask"

\section{Anesthesia Post-Project Responses}

"Twice I transferred patients to the ICU and the nurses were too busy to receive an in depth report" easier to do this handoff with them present at the time as well, but sometimes they are not available." 
"I think it is important to have the SICU nurse to identify their role when we arrive. Everyone is trying to get the patient reconnected and they have a lot of help during this process. This past weekend it was very nice transition. The nurse did identify herself and it was very easy transfer of care. There was a lot of people in the room and it was busy. The nurse to identify herself and it made the transfer of care very nice."

"The SICU RN seldom seems interested in getting report from anesthesia when we return with the patient. I feel like I am bothering them if I am trying to give them report."

"It's often difficult to find the bedside nurse"
"The report sheet worked well when nurses used it. There was inconsistency with using it though"
"I didn't know nurses liked all of this information in report. It's good to know they care about all this pertinent info"

"I don't think everyone was on board with this in SICU, it seemed very inconsistent to me." "This worked great when I dropped a patient off to the SICU"

"Some nurses used the report and some didn't because they were too busy"

"Leaving name and number of responsible anesthesia clinician so that ICU clinicians can call to clarify something as they start treating the patient."

"This worked well when it was actually used. Some situations it wasn't used for report and report was scattered"

"SICU should stop and listen to report before touching the patient. No SICU nurses should be unplugging monitors until the full bedside report is given by anesthesia. Frequently anesthesia is bringing unstable and sick patients that are on pressures or need blood pressures treated. Before the SICU staff knows anything about the patient A-line is disconnected and placed under the bed with no blood pressure monitoring. I also suggest that the A-lines not be placed under the bed, the cord needs to be freely hanging so that if the patient needs to go to OR STAT then the OR staff can take them without having to unplug the cable and taking it out from under the bed."

"Not all of the bedside nurses seemed to care about a thorough report, but the ones that did use the report sheet did a great job and asked good questions" 
"The nurse did not seem to care about report when I took a patient to SICU"

"Not every nurse used the report sheet, but when they did the report flowed very well"

\section{Surgery Pre-Project Responses}

"The nurses are too busy with the patient to give report"

"Too many people are talking at once. Nurses are too busy with the patient"

"Too many people in the room at once. It's difficult finding who to give report to"

"Nurse is hard to identify"

"Hard to find nurse"

\section{Surgery Post-Project Responses}

"The rooms are way too busy with nurses to give them report"

"Nurses asked appropriate questions"

"Nurses were too busy to get report so I gave report to the ICU staff in charge"

"It was helpful when the bedside nurse asked for a report"

"Too inconsistent. It was helpful when the nurses were engaged and identified themselves"

"I was satisfied with the quick report and I didn't have to repeat myself a bunch of times" 